\title{
Contribution to the genus Diploneis (Bacillariophyta): Twelve species from Holarctic freshwater habitats proposed as new to science
}

\author{
Horst LANGE-Bertalot ${ }^{1} \&$ André FuHRMANN $^{2}$
}

\author{
${ }^{1}$ Institute for Ecology, Evolution, Diversity, Goethe-University Frankfurt, Biologicum, Max-von-Laue-Str. 13, \\ 60439 Frankfurt am Main \\ ${ }^{2}$ Fachbereich 8, Goethe-Universität Frankfurt, Grüneburgplatz 1, 60629 Frankfurt am Main; Corresponding \\ authore-mail: fuhrmann@em.uni-frankfurt.de
}

\begin{abstract}
Numerous questionable extant populations of Diploneis with cribrate areolae are morphologically compared (in LM and SEM) to resembling established taxa. In most of these examinations the types are available and documented in the literature by several authors during the last forty years. All taxa in question belong ecologically to the minority of Diploneis that live exclusively in freshwater. As main result twelve species from Europe and one from Florida, U.S.A., are selected and proposed as new to science. These are: $D$. abscondita, D. calcilacustris, D. hinziae, D. lusatica, D. modicahassiaca, D. oblongellopsis, D. praetermissa, D. puellafallax, D. tirolensis, all from Central Europe (Austria, Germany, Switzerland); D. nanofontanella and D. tundra from European Arctic Russia; and D. parahinziae from Florida. After critical examination, D. arctica stat. nov., D. ladogensis stat. nov., and D. dilatata stat. nov. are proposed to be transferred from infraspecific to species rank.
\end{abstract}

Key words: Autecology, Bacillariophyta, biogeography, cribra, diatoms, Diploneis, Europe, freshwater, ultrastructure

\section{INTRODUCTION}

The large majority of known Diploneis taxa live in marine habitats, many of them being cosmopolitan, whereas comparatively few inhabit freshwater habitats. The latter are restricted to distinct biogeographical plant realms such as the Holarctic, the Paleo- and Neotropics. Over many decades of the 20th century the European watercourses have suffered from strong eutrophication and organic pollution. Since Diploneis is rather intolerant to such conditions the huge rivers in Germany, Poland and France have been widely devoid of Diploneis species. All populations described and discussed in this paper originate from stagnant oligoto slightly eutrophic waters - with the exception of one pond-effluent.

Hustedt (1930) distinguishes no more than ten taxa for Central Europe. The last comprehensive treatise on Diploneis has been Hustedt (1937), including fifteen taxa which inhabit freshwater of North and Central Europe. His conceptions of freshwater species have been perpetuated since then, i.e. over a period of more than seventy years without thorough actualisation. Cleve-Euler (1953) has added some new taxa from Scandinavia but mainly extending extant species concepts. PAtrick \& Reimer (1966) report fourteen for North America, including many brackish water taxa. More recently Germain (1981) counts eight taxa in South-West France. Krammer \& Lange-Bertalot (1986) list seventeen freshwater and seven brackish water taxa in almost entire Europe. In the Red List of endangered species in Germany and neighbouring countries from 1996 (LANGE-BERTALOT 1996) this number had not increased. In their recent atlas of diatoms, covering numerous large and small watercourses in the rather large monitoring area of the Rhône-Alpes region in France, BEY \& ECTOR (2013) end up with only five established plus two non-identified species of Diploneis. Their studies, mainly carried out between 2007 and 2011, covered 157 sampling stations and pertain not only to the Rhône catchment area but also cover part of the Loire river area with its tributaries from the Eastern Central Massif mountains. Even though the geological and ecological variability of the investigated sites is thus very high, it yields a surprisingly low number of Diploneis taxa. Moreover, it should be mentioned that BEY \& ECTOR take into consideration new taxonomical results concerning the genus that have become available only after the appearance of the comprehensive "Süßwasser-Flora" (KRAMMER \& 
LANGE-Bertalot 1986). Since then new freshwater taxa of Diploneis had not only be described from South America, Asia, and the paleotropical Pacific island of New Caledonia, but likewise from Europe. New (since Krammer \& Lange-Bertalot 1986) taxa from Europe are:

Diploneis ovalis ssp. arctica LANGE-BERTALOT in Lange-Bertalot \& GenKal 1999,

D. krammeri Lange-Bertalot \& ReICHARDt 2000,

D. fontium Reichardt \& Lange-Bertalot 2004,

D. fontanella Lange-Bertalot in Werum \& LANGE-Bertalot 2004,

D. separanda LANGe-Bertalot in Werum \& LANGE-Bertalot 2004.

We may mention that a noteworthy location for endemic Diploneis species is Lake Ohrid (Macedonia/ Albania). From fifteen species recently presented in JovANOVSKA et al. (2013), five are described as new.

As explained in more detail in the Discussion (see below), freshwater Diploneis fall into few conspicuous groups that combine certain morphological features of the valve, particularly concerning their patterns of areolae. The group under study here comprises species that exhibit cribrate areolae of various size, arranged in uniseriate or biseriate, rarely pluriseriate striae. Also included here are species where striae gradually switch over from a uniseriate to a bi- or pluriseriate pattern. As far as we know, this group happens to be the by far most populated by freshwater taxa of the genus Diploneis in Europe and elsewhere.

Dedication. Friedel Hinz has served the diatom community for many decades as curator of one of the world's most important diatom collections, the Friedrich Hustedt-Archives in Bremerhaven. As in countless other cases over the years, she has helped the authors of the present study by providing photographs of the taxon that Hustedt took to be Diploneis parma, one of the starting points for this investigation. We dedicate the newly described taxon, Diploneis hinziae, to her on the occasion of her retirement.

\section{Materials And Methods}

These observations on taxonomically critical Diploneis populations have been carried out during fifteen years since 1999. Samples have been taken sporadically over a longer period from 1982 up to 2011. Colleagues, friends and former students have collected from mainly stagnant freshwater in various regions of Germany, Austria, Switzerland, European Russia and Florida, U.S.A. Those who provided us with samples, slides or ecological data, as far as available, are mentioned under the typifications of the new taxa. Usually the samples were given to us with the intent of asking for identification of critical diatom taxa in general rather than for the purpose of investigating specifically the genus Diploneis. However, in the course of time, data of questionable Diplo- neis specimens in slides were recorded or marked with coordinates in different light microscopes. The following light microscopes were used: Leitz Ortholux, Leitz Dialux, Leitz Diaplan, Zeiss Standard Universal, Nikon Eclipse E600. All micrographs were taken with apochromatic lenses of aperture no less than 1.3. Brightfield illumination, film (Agfa Ortho Professional), and for more recent work digital photographic equipment was used throughout. SEM studies were carried out with a Hitachi S-4500 at the Goethe-Universität Frankfurt am Main, operated at $10 \mathrm{kV}$ by Manfred Ruppel. For the purpose samples were fixed on aluminium stubs and sputtercoated with $40 \mathrm{~nm}$ gold.

As samples, including slides, reached us from various sources, a number of standard cleaning methods were employed. Most samples were cleaned by oxidisation in hot sulphuric acid or in hot hydrogen peroxide with potassium permanganate added. In some cases a pre-cleaning in $\mathrm{HCl}$ was necessary to remove calcareous matter. All material for LM was mounted in Naphrax with a refractive index of ca. 1.7 .

\section{Results}

In this section we describe species proposed as new to science and new combinations of established taxa. Although some of these taxa are morphologically closely related, such as $D$. hinziae and D. parahinziae, we present them, for the reader's convenience, in strict alphabetical order.

Diploneis abscondita LANGe-Bertalot et G. HofMANN sp. nov. (Figs 1-7 LM, 106-108 SEM external view)

\section{Diagnosis}

Valvae ellipticae ad lineari-ellipticae cum facie arcuata in limbos apicibus late rotundatis. Longitudo 18-40 $\mu \mathrm{m}$, latitudo 8-15 $\mu \mathrm{m}$. Ratio longitudo/latitudo 1.8-2.7. Raphe filiformis recta poris centralibus parvis vix dilatatis aliquid distanter sitis extremis terminalibus deflexis unilateraliter usque ad limbum valvae. Area axialis anguste lanceolata. Area centralis parva vel moderate dilatata semper distincte separata $a b$ area axiali fere elliptica ad instar. Appendices in forma litterae $\mathrm{H}$ vix formatae. Canales axiales interni cum seriebus compositis pluribus areolis fere indistinctis aream rhombico-lanceolatam formantes. Striae transapicales regulares radiantes omnino, 13-15 in $10 \mu \mathrm{m}$ uniseriatae sed transientes biseriatae cum areolis oppositis prope margines faciei valvae et ad limbos. Numerus areolarum $13-18$ in $10 \mu \mathrm{m}$. Aspectus ultramicroscopicus externus vide Figs 106-108. Vide particulariter raphem cum extremis terminalibus longius deflexis in limbos valvae. $D$. hinziae differt proprie canalibus axialibus angustioribus latitudine superiori $(10-23 \mu \mathrm{m})$ ratione longitudo/latitudo minori (1.3-1.6) et area centrali minus expansa.

Holotype (designated here): Slide G. Hofmann no. 


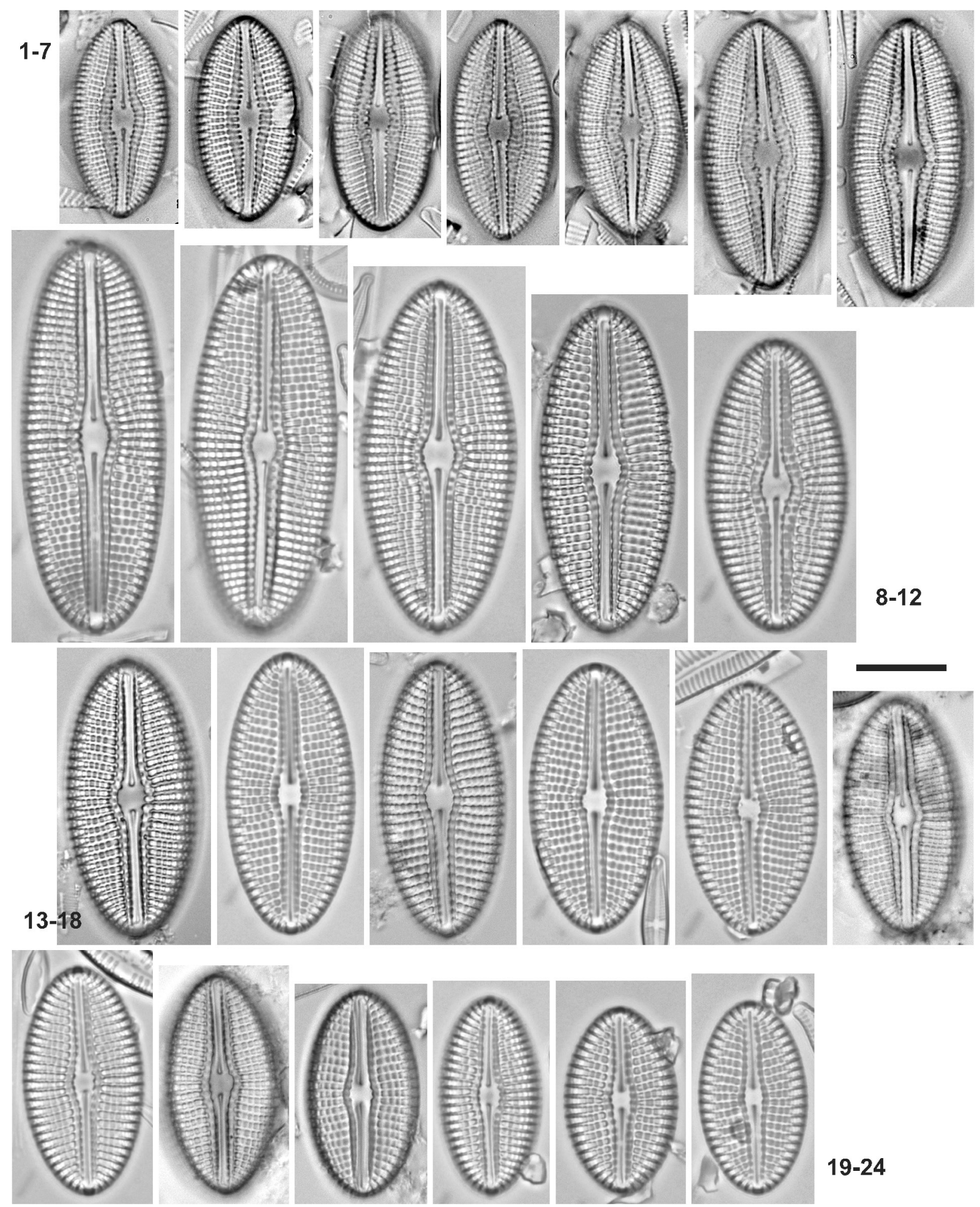

Figs 1-24. LM: Diploneis abscondita sp.nov., Marbe pond effluent, Saxony, Germany, (6) designated holotype. Striae turning from uni- to biseriate near the valve margins; areolae opposed, not alternating; (8-24) D. calcilacustris sp.nov., Lake Mainflingen, near Hanau, Hassia, Germany (Figs 11, 13, 15, 18, 20, 21), Lake Bohinj, Julian Alps, Slovenia (Figs 8-10, 12, 14, 16, 17, 19, 22-24), (10) designated holotype. Scale bar $10 \mu \mathrm{m}$ 
5702 in Coll. Lange-Bertalot, Naturmuseum Senckenberg, Frankfurt (FR); material no. 414650. Represented by Fig. 3.

Type locality: Marbegraben, brook in StaßfurtGlöthe, Sachsen-Anhalt, Germany, effluent from pond Ruschenschacht (former mining excavation); leg. M. Werum 16.7.2010.

Etymology: The Latin adjective abscondita means hidden and refers to the so far overlooked occurrence.

\section{Description}

Valves elliptical to linear-elliptical with bluntly rounded ends. Only central parts of the valve face are almost flat, whereas marginal parts become arcuate as they gently merge into the poorly differentiated mantle. Length $18-40 \mu \mathrm{m}$, breadth $8-15 \mu \mathrm{m}$. Lengthto-breadth ratio 1.8-2.7. Raphe filiform, straight, with slightly expanded central endings which are moderately widely spaced; longer terminal fissures bent onto the same side of the valve mantle. Axial area narrow but expanded lanceolate towards the centre. Central area rather small with variable outlines, often apically elliptical, but clearly separated in all cell-cycle stages. H-shaped appendices barely developed. Axial internal canals are marked outside by transapical striae composed of three or four areolae, altogether forming a conspicuous rhombical-lanceolate area being softly arched around the central nodule. Adjacent regular striae radiate throughout, $13-15$ in $10 \mu \mathrm{m}$, uniseriate but becoming biseriate near the valve margins onto the mantle. The areolae are opposed, not alternating, appearing here as single puncta in LM (cf. SEM Figs 106-107). Number of areolae in $10 \mu \mathrm{m}$ is $13-18$. SEM external view see Figs 106-108. Note in particular the raphe central and distal endings and the arrangement of cribrate areolae gradually cleaved with opposed parts.

\section{Differential description}

Taxa more or less similar as to outlines and size dimensions possess different fine structure patterns.

\section{Distribution and ecology}

As yet critically observed only at the type location. This is a moderately eutrophic "hard-water" brook (slowly flowing, width $1 \mathrm{~m}$, depth 10-30 cm) with a species-rich diatom assemblage typical of anthropogenically unpolluted and electrolyte-rich, not yet brackish water (sulphate ions $800-2000 \mathrm{mg} . \mathrm{l}^{-1}$, conductivity $\left.1500-2500 \mu \mathrm{S} . \mathrm{cm}^{-1}\right)$.

\footnotetext{
Diploneis arctica (LANGE-BERTALOT) LANGE-BERTALot et A. Fuhrmann stat. nov. (Figs 41-42)

Basionym: Diploneis ovalis ssp. arctica LANGE-BERTALOT in LANGEBertalot \& GenKal 1999, Iconographia Diatomologica 6, p. 43, figs 43: 1-3, 44a: $1-5$.

A critical examination of the distinctive characters separating ssp. arctica from the nominate subspecies $D$. ovalis, as emended in LANGE-BeRTALOT \& REICHARDT 2000, makes a separate species rank more appropriate
}

rather than assessing the two taxa as conspecific. This receives support when comparing microphotographic records in as yet unpublished work by E. Pinseel based on samples from Spitsbergen. The similarity with respect to the broadly elliptical outline and the shape of the large central area may have been overestimated while the significantly higher density of striae and areolae of the Arctic taxon has been downplayed. We also note that when the Arctic taxon was established in 1999, the type material of $D$. ovalis (HILSE) RABENHORST had not yet been available for SEM investigation.

Striae 17-19 in D. arctica (versus 11-15) in 10 $\mu \mathrm{m}$, areolae 15-21 (not 12-15) in $10 \mu \mathrm{m}$. Moreover, the shape of the domed valves and the detailed pattern of areolation are clearly distinct between the two taxa; cf. Lange-Bertalot \& GenKal (1999, plates 43-44b) and Lange-Bertalot \& Reichardt (2000, plates 1-3). As to Diploneis ovalis (Hilse) Cleve ssp. ovalis sensu Lange-Bertalot \& GenKal 1999, figs 44b: 1-3 in particular, conspecificity with the lectotypified population of Navicula ovalis in RABENHORST, Algen Europas, Exsiccat no. 1025, appears unlikely.

Diploneis calcilacustris LANGE-BERTALOT et A. FuHRMANN Sp. nov. (Figs 8-24 LM, 109-111 SEM external and internal views)

Synonyms: Diploneis ovalis sensu FogED 1976, fig. 2: 13; Diploneis parma sensu LANGe-Bertalot \& MetZeltin 1996 pro parte, i.e. fig. 85: 5; Diploneis parma sensu Hofmann et al. 2013, fig. 65: 10; Diploneis parma sensu Krammer et Lange-Bertalot as documented by Bey \& Ector 2013, p. 415, figs 1-19.

\section{Diagnosis}

Valvae ellipticae ad lineari-ellipticae apicibus cuneatim rotundatis. Longitudo $20-45 \mu \mathrm{m}$, latitudo $12-17$ $\mu \mathrm{m}$. Ratio longitudo/latitudo 1.6-2.7. Raphe filiformis recta poris centralibus distincte dilatatis sitis in area axiali angusta lineari. Area centralis parva elliptica circiter 1/4-1/5 latitudinis valvae extendens. Appendices areae centralis minime formatae. Depressiones ad raphem utrimque non vel leviter aspectabiles microscopio photonico. Canales apicales interni angusti cum una serie punctorum separata a striis transapicalibus. Istae striae distincte radiales omnino, 10-12 in 10 $\mu \mathrm{m}$. Areolae $12-15$ in $10 \mu \mathrm{m}$ uniseriatae in partibus adaxialibus et biseriatae prope margines valvarum aut oppositae vel alternantes. Aspectus ultramicroscopicus externus internusque vide Figs 109-111.

Holotype (designated here): Slide Seen 224 in Coll. Lange-Bertalot, Naturmuseum Senckenberg, Frankfurt (FR), represented by Fig. 10.

Type locality: Lake Bohinj, a calciumcarbonate-rich lake in the Julian Alps, Slovenia.

Etymology: The Latin epithet combines reference to the element calcium (calx) with the adjective lacustris (from lacus $=$ lake). This species can be observed almost exclusively in carbonate-rich lakes. 


\section{Description}

Outlines strictly elliptical to oblong-elliptical, more or less cuneately rounded ends. Length $20-40 \mu \mathrm{m}$, breadth 12-16 $\mu \mathrm{m}$, length-to-breadth ratio 1.6-2.7. Raphe filiform, straight with distinctly expanded central ends and shortly curved distal ends. Axial area narrow. Central area elliptical, expanded transapically $1 / 4$ to $1 / 5$ of the valve breadth. $\mathrm{H}$-shaped appendices (so-called horns in the literature) weakly developed. Internal depressions parallel to the raphe slit, visible in LM view by focusing. Apical internal canals marked by a single or two apertures to the valve outside, closely adjacent to the transapical striae, being moderately radiate throughout or somewhat stronger radiate close to the apices, $10-12$ in $10 \mu \mathrm{m}$. Areolae 13-15 in $10 \mu \mathrm{m}$, appearing uniseriate with exception of a few ones close to the margins where they become biseriate in each stria. SEM external and internal view see Figs 109-111.

\section{Differential description}

D. hinziae sp. nov., living in electrolyte-poor waters of the Alps and in the Arctic/sub-Arctic regions, has almost the same cell sizes, striation and areolation but differs in its characteristic outlines, being more broadly elliptical with bluntly rounded apices. The central ends are more widely spaced in specimens of comparable size. The extension of the central area of $D$. hinziae displays less transapical asymmetry, the secondary side of the valve being distinctly more curved in $\mathrm{D}$. calcilacustris. The striae are less radiate proximally, each exhibiting more areolae due to the broader valve shape. D. parahinziae from subtropical Florida, U.S.A., found in acidic water, differs likewise in having broader linear-elliptical valve outlines with more broadly rounded ends, a higher striae- and areolae density, the latter being 15-20 (vs. 13-15) in $10 \mu \mathrm{m}$. Areolae of the valve face are for the larger part cleaved and arranged in an alternately biseriate pattern. The canal areolae are smaller proximally.

D. elliptica (Kützing) Cleve (Fig. 125, as associated with the type population) is mainly distinguished by an approximately equal striae- and areolae density of 8-10 in $10 \mu \mathrm{m}$; see likewise type specimens in LANGe-Bertalot \& Reichardt 2000. Areolae are not divided. Central area is more broadly extended in comparable stages of both taxa. In internal SEM view $D$. elliptica shows broader virgae between narrower aveoli in contrast to D. calcilacustris with its equally broad virgae and aveoli; compare Fig. 111 with fig. 84: 10 in ZeLAZNA-WieCZOREK (2011).

\section{Distribution and ecology}

Infrequent but moderately abundant in places. These are oligo- to mesotrophic, generally oligosaprobic, calciumcarbonate-rich lakes, fountains, or springs in Europe.

\section{Taxonomical comments}

This taxon has been recorded and repeatedly documented photographically under various established names of Diploneis; see under Synonyms above. It is sometimes associated with rather resembling populations (morphodemes) which differ mainly by higher striae and areolae densities: 12-17 (vs. 10-12) striae and 1520 (vs. 13-15) areolae in $10 \mu \mathrm{m}$. They will be subject to investigation in a separate publication.

\section{Diploneis dilatata (M. Peragallo) Lange-Bertalot} et A. Fuhrmann stat. nov. (Fig. 124)

Basionym: Navicula smithii var. dilatata M. Peragallo in Tempère \& Peragallo 1908, Diatomées du Monde Entier, 2nd. ed., p. 56, no. $103-104$.

Synonyms: Diploneis smithii var. dilatata (M. Peragallo) Terry 1908, "Additional lists of Connecticut diatoms", Rhodora 10, p. 182.; Diploneis smithii var. dilatata (M. Peragallo) Boyer 1927, Proc. Nat. Acad. Sci. Philadelphia 79(2), Suppl., p. 355.

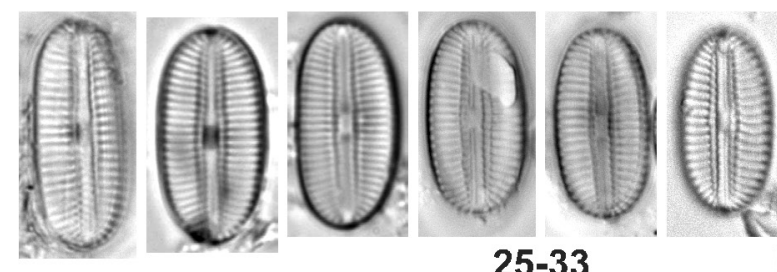

25-33

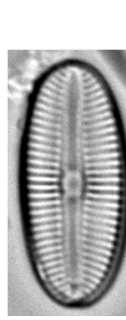

34-40
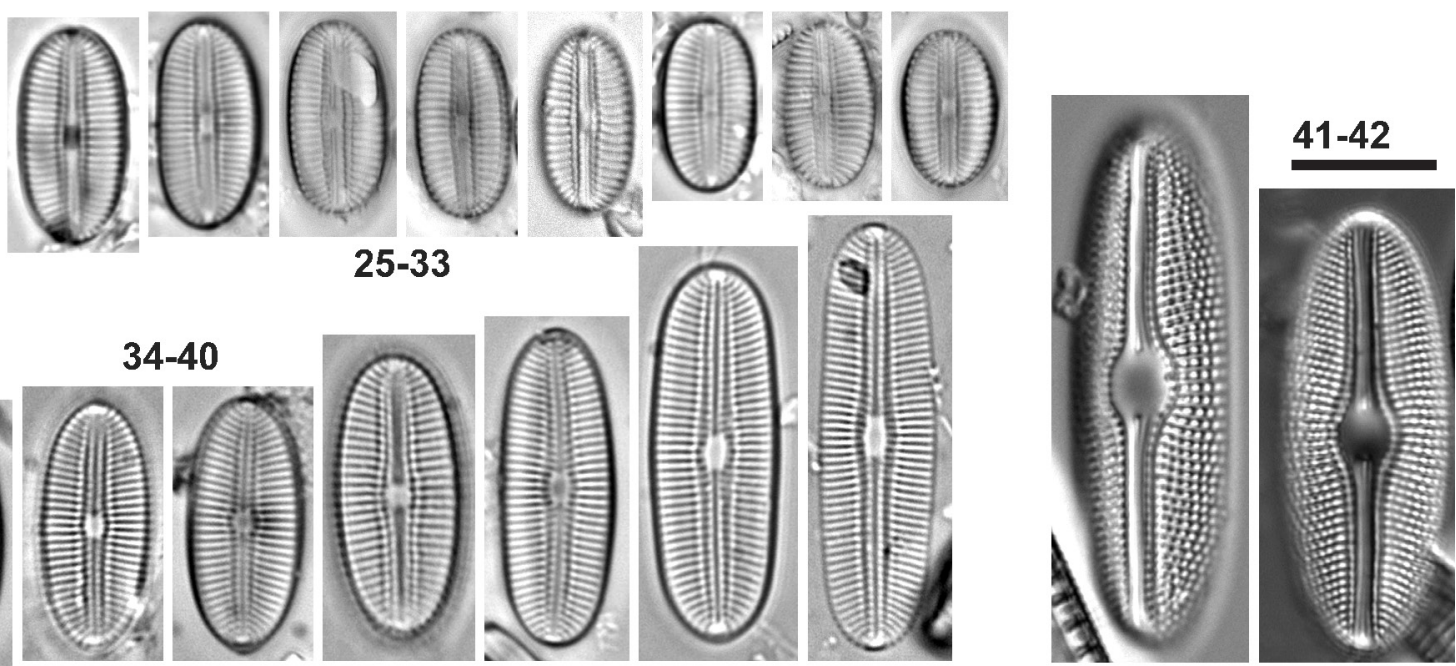

Figs 25-42. LM: Diploneis modicahassiaca sp.nov., Mainflingen, (29) designated holotype; (34-40) D. praetermissa sp.nov., Weissensee, Tyrol, Austria, (39) designated holotype; (41-42) D. arctica stat.nov., Spitsbergen. Scale bar $10 \mu \mathrm{m}$. 
PATRick \& Reimer (1966, p. 411, fig. 38: 3) give a line drawing of a specimen from the type population in freshwater, Fall Mountain, Bristol, Hartford Co., Connecticut. For a recent microphotograph, taken by $\mathrm{M}$. Potapova, from the lectotype-slide, see Fig. 124.

The outlines, longitudinal canals, and the central area with $\mathrm{H}$-shaped appendices clearly differ from Diploneis smithii (Brébisson ex W. Smith) Cleve 1894 var. smithii. From the present taxonomical point of view conspecificity must be excluded. Moreover, the "second hand" concept of Diploneis smithii var. dilatata illustrated in KRAMMER \& LANGE-BERTALOT (1986, fig. 112: 4) is obviously incorrect: there can be little doubt that these specimens from the Baltic Sea represent another species that morphologically clearly differs from Peragallo's freshwater taxon and thus needs a revision.

Diploneis hinziae Lange-Bertalot et A. Fuhrmann sp. nov. (Figs 43-50 LM, 113ab-114 SEM external and internal views)

Synonyms: D. parma Cleve sensu HustedT 1937; fig. 1066 (specimen on the right-hand-side); D. parma Cleve sensu KRAMMER \& LANGE-Bertalot 1986; figs 109: 1-4.

Diagnosis differens versus Diploneis parma CLEVE 1891

Valvae late ellipticae quoad specimina minora et late lineari-ellipticae quoad specimina maiora (numquam latius ellipticae ad leviter rhombico-ellipticae). Apices latissime rotundati (non cuneatim rotundati). Longitudo valvarum populationis typici $23-50 \mu \mathrm{m}$, latitudo 15-18 $\mu \mathrm{m}$. Ratio longitudo/latitudo 1.5-2.8 (nec 1.3-1.6). Raphe filiformis extremis centralibus modice distanter sitis inter se et extremis terminalibus curte unilateraliter deflexis. Area axialis angusta, linearis cum depressionibus internis utrimque ad raphem angustis sed dilatis proximaliter ad extrema centralia raphis. Area centralis parum dilatata ita semper parva (nec distincte expansa) circiter elliptica. Appendices areae centralis "cornua" dicta vix vel plerumque leviter formatae. Canales apicales interni fere angusti zonam anguste lanceolatam circum aream centralem facientes cum una vel duobus seriebus punctorum separatis a striis transapicalibus regularibus. Istae striae leviter tum modice radiales in mediis partibus valvae, $11-12.5$ in $10 \mu \mathrm{m}$ quoad populationem typicam compositae areolis duplicibus in partibus marginalibus sed singulis in partibus adaxialibus, $14-15$ in $10 \mu \mathrm{m}$ quoad populationem typicam.

Holotype (designated here): Slide O 4/57 in Coll. Hustedt, AWI, Bremerhaven, Fig. 45 representing holotype specimen.

Type locality: Unterer Grialetschsee, near Davos, Switzerland, $2500 \mathrm{~m}$ a.s.l. (Photographs taken by Friedel Hinz.)

Etymology: We dedicate this taxon to Friedel Hinz, long-time curator of the Friedrich Hustedt-Archives in Bremerhaven.

\section{Description}

Valves of smaller specimens are broadly elliptical, the larger broadly linear-elliptical, all with very bluntly rounded apices. Length of type specimens 23-50 $\mu \mathrm{m}$, breadth 15-18 $\mu \mathrm{m}$. Length-to-breadth ratio 1.5-2.8. Raphe filiform, straight, moderately expanded towards the central ends which are slightly deflected like the short terminal fissures to the same side of the valve. Narrow apical depressions are flanking the internal raphe slit. The axial area as a whole is (very) narrow, almost linear; so-called H-shaped appendices or horns are very weakly developed. The central area is small and elliptical. The apical zone above the internal longitudinal canals is narrow, slightly arched around the central nodule, marked by a single or double row of puncta. Regular transapical striae, $11-12.5$ in $10 \mu \mathrm{m}$, are weakly radiate or subparallel at the valve centre, becoming moderately more strongly radiate near the apices. Areolae appear simple closer to the raphe sternum, becoming doubled in the marginal parts, 14-15 in $10 \mu \mathrm{m}$. SEM, external and internal view, see Figs 113ab-114. All areolae are cribrate, other features as seen in LM view are confirmed.

\section{Differential description versus Diploneis parma Cleve 1891 sensu stricto}

Cleve's taxon is distinguished by a consistently broader, almost rhombic-elliptical valve with slightly cuneately rounded ends. Its length-to-breadth ratio is 1.3-1.6 versus $1.5-2.8$ for $D$. hinziae. Moreover, the areola density is higher on average, approximately 20 in $10 \mu \mathrm{m}$. For detailed analyses of the type population and others, including fine structures in SEM and TEM, see IDEI \& KOBAYASI (1988).

\section{Distribution and ecology}

Evidently very uncommon in Central Europe but moderately abundant at the type location where it is associated with predominantly acidophilous diatom taxa under low alkalinity and conductivity conditions. From Finland documented by KRAMMER \& LANGE-BERTALOT (1986, figs 109: 3-4); from Spitsbergen (Svalbard) documented with microphotographs by E. Pinseel (University of Ghent). Distribution may be "nordic-alpine". Records under the name Diploneis parma from Europe belong neither to the true $D$. parma nor to $D$. hinziae but to an as yet undescribed taxon. See e.g. BLANCO et al. (2010, figs 50: 30-33).

\section{Comments}

D. hinziae has been mistaken for D. parma by several authors in the past. As one of the first authors, Hustedt (1937; 1943, p. 150) has enlarged the original concept of D. parma inappropriately. His fig. 1066 (1937, p. 674 ) illustrates two heterogeneous specimens, the left one representing a specimen from Sweden. That specimen is not from the lectotype material (Lake Lojo, Finland), selected later on by IDEI \& Kobayasi (1988), but 


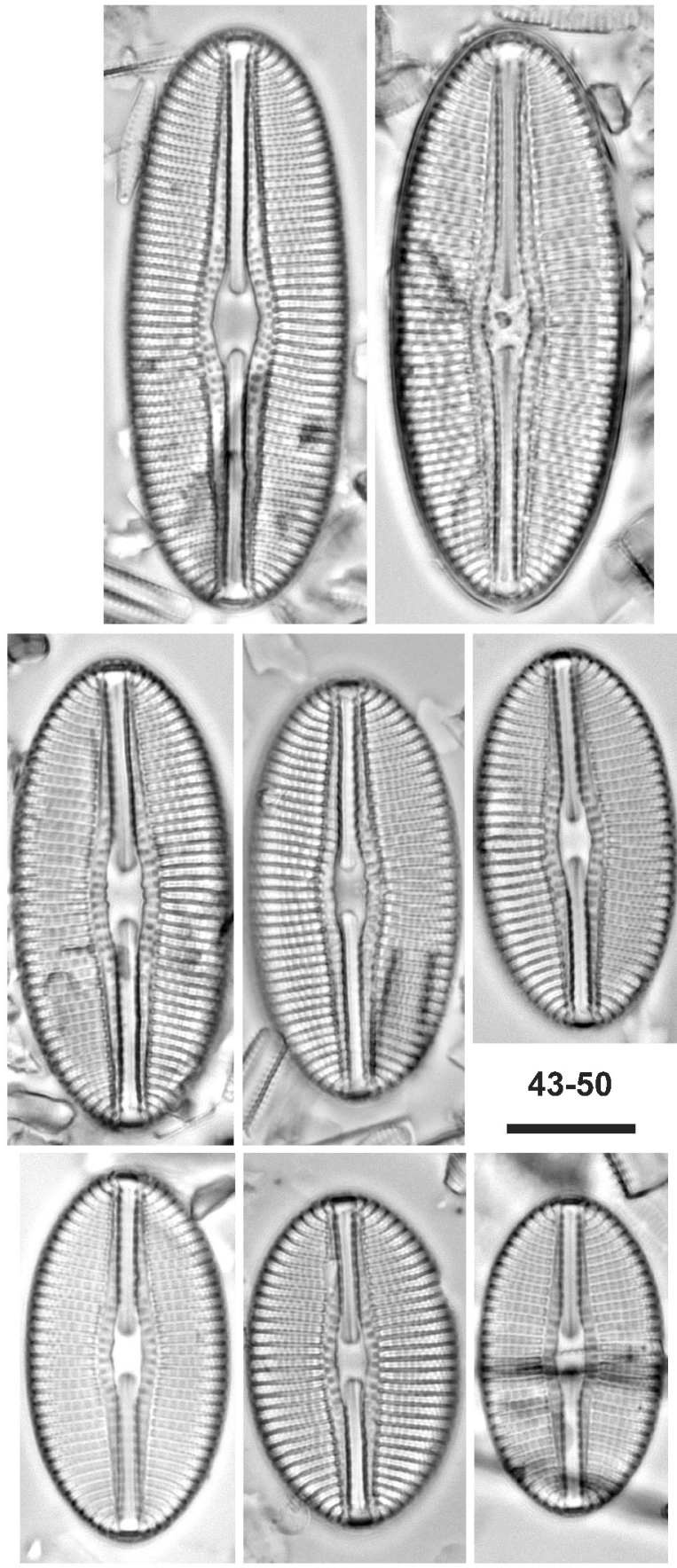

Figs 43-50. LM: Diploneis hinziae sp.nov., Grialetschsee, near Davos, Switzerland, (45) designated holotype. Scale bar $10 \mu \mathrm{m}$.

from Rosslängen, Smaland in Sweden, another syntype among three locations mentioned by CLEVE (1891). The difference to the specimen on the right in fig. 1066, originating from "Unterer Grialetsch See" in Switzerland, is quite obvious. However, Hustedt acknowledged only minor differences and treated both as representatives of a single taxon. KRAMMER \& LANGE-BERTALOT (1986, figs 109: 1-2) uncritically followed Hustedt's ambiguous concept. Thus, it appears that not all of the specimens identified erroneously in KRAMMER \& LANGEBertalot (1986) as D. parma belong to D. hinziae; fig.
109: 5 may not fit the given scale of $\times 1500$ but $\times 1000$; figs 109: 6-7 may belong to another taxon together with “D.parma" sensu Lange-Bertalot \& Metzeltin (1996, figs 85: 6-7).

\section{Diploneis ladogensis P.T. CLEVE}

Basionym: Diploneis elliptica var. ladogensis P.T. Cleve 1891, The diatoms of Finland, Acta Soc. Fauna et Flora Fennica 8(2), p. 43, fig. 2: 9.

Comparing critically the photographic illustrations of this taxon in the literature, there is no doubt that conspecificity has to be excluded. See e.g. LANGE-BERTALOT \& REICHARDT (2000), figs 7: 1-3, representing stages from the type population of Navicula elliptica Kützing (slide B.M. 18739). On the other hand, for $D$. elliptica var. ladogensis see Cleve-Euler (1953, figs 646A: b,c); Krammer \& Lange-Bertalot (1986, figs 108: 3,5); Foged (1981, fig. 14: 8).

Independently of the present authors, JovanovsKA, LEVKOV \& EDLUND (forthcoming 2015) also come to the conclusion that the taxon, as observed in Lake Hövsgöl, Mongolia, ought to be elevated to species rank; cf. the detailed discussion in their article.

\section{Diploneis lusatica Lange-Bertalot et G. Hofmann sp. nov. (Figs 51-57 LM, 115-118 SEM external and internal views) \\ Diagnosis differens versus Diploneis subovalis P.T. Cleve 1894}

Valvae late ellipticae ad plerumque aliquid rhombicoellipticae (nec ellipticae ad leviter lineari-ellipticae) apicibus fere cuneatim late rotundatis. Facies valvarum paulatim in limbos curvata. Longitudo $20-50 \mu \mathrm{m}$, latitudo 13-23 $\mu \mathrm{m}$. Ratio longitudo/latitudo 1.4-2.2. Raphe paene recta filiformis extremis centralibus terminalibusque fere curte ad idem latus valvae deflexis poris centralibus parum dilatatis. Area axialis et depressiones axiales parallelae prope raphem non differentes. Area centralis generaliter anguste elliptica cum area axiali continuum formans sed in media parte plerumque plus minusve constricta, ita paene rectangulata apparens (differt ab area fere lata iconotypi ex Nova Zealandia). Zona apicalis lanceolata supra canales internos cum striis transapicalibus curtis compositis paucis areolis irregulariter sed semper uniseriatis. Striae transapicales regulares omnes radiatae biseriatae 8-10 in $10 \mu \mathrm{m}$. Areolae duplicatae alternantes $18-20$ in 10 $\mu \mathrm{m}$. - Aspectus ultramicroscopicus externus internusque vide Figs 115-118.

Diploneis pseudovalis Hustedt 1930 proprie differt quoad lineamentum plerumque lineari-ellipticum et dimensiones inferiores, 16-31 $\mu \mathrm{m}$ longas, 8-14 $\mu \mathrm{m}$ latas etiam habitat in aquis subsalsis. Diploneis smithii (BRÉBISSON) CLEVE habitat cum populationibus diversissimis et certe heterospecificis in aquis marinis vel subsalsis differt proprie structura speciosa supra canales internas atque area centrali vix dilatata et numquam constricta in medio quamquam individua dicta Diplo- 
neis smithii var. dilatata (Peragallo) Terry 1908 pro parte (vide WiTKOWSKI et al. 2000, figs 90: 5-6) vero similes apparentia.

Holotype (designated here): Slide S-2519, Seen no. 225 (G.H. 2762) in Coll. Lange-Bertalot, Naturmuseum Senckenberg, Frankfurt (FR), represented by Fig. 53.

Type locality: Water reservoir of Spremberg, Lausitz region, Saxony, eastern Germany; leg. 4.8.2008.

Etymology: The name of the German region Lausitz (in Slavic languages "Luciza") was in Roman times Lusatia (adj. lusatica). It refers to the type locality in the wetlands between the river Görlitzer Neiße and the upper part of the river Spree.

\section{Description}

Valves broadly elliptical to almost rhombic-elliptical with somewhat cuneately, bluntly rounded ends. Valve face flat in the central part, whereas the large marginal part is domed and merged gradually into the mantle. Length 20-50 $\mu \mathrm{m}$, breadth 13-23 $\mu \mathrm{m}$. Length-tobreadth ratio 1.4-2.2. Raphe filiform and almost straight, both central and terminal ends shortly deflected to the same side of the valve. Central pores inconspicuous. Axial area with apical depressions flanking the raphe slit internally, narrow, slightly expanded towards the central area which appears more or less constricted in the middle by few transapical striae, whence almost rectangular in shape in most specimens. The apical zone with underlying longitudinal canals is marked by short striae composed of few puncta. Regular transapical biseriate striae, $8-10$ in $10 \mu \mathrm{m}$, radiate throughout, each composed of alternating double areolae, 18-20 in $10 \mu \mathrm{m}$. - SEM external and internal views, see Figs $115-118$

\section{Differential description}

Diploneis pseudovalis Hustedt 1930 differs mainly by the linear-elliptical outline of most specimens, smaller dimensions on average, 16-31 $\mu \mathrm{m}$ long, 8-14 $\mu \mathrm{m}$ broad, and autecology, living in saline springs. $\mathrm{Di}$ ploneis subovalis CLEVE 1894, at least the type from freshwater in New Zealand, differs mainly in its slightly linear-elliptical outline (instead of rhombic-elliptical), and its larger, elliptical (instead of constricted to rectangular) central area. Diploneis smithii (BRÉBISSON) CLEVE 1894 certainly represents a heterospecific complex of taxa. The nominate variety is significantly larger celled with a less expanded central area and living in marine and brackish habitats. However, Diploneis smithii var. dilatata (Peragallo) Terry 1908 in the sense of several authors (e.g. WitKowski et al. 2000, figs 90: 5-6) is quite similar. Nevertheless, any conspecificity with the nominate variety can be excluded and in the rank of a variety Peragallo's taxon has no priority.

\section{Distribution and ecology}

Very abundant at the type locality, a large artificial lake, eutrophic but oligosaprobic freshwater with slightly elevated conductivity, 800-900 $\mu \mathrm{S} . \mathrm{cm}^{-1}$. Associated taxa are various Planothidium species and, in particular, the commonly infrequent Navicula oppugnata, together with Navicula gregaria, N. germainii, $N$. viridula, $N$. amphiceropsis (see LANGE-BERTALOT 2001). Remarkable is the high content of sulphate, ca. $300 \mathrm{mg} . \mathrm{l}^{-1}$, due to mining activities upstream.

\section{Diploneis modicahassiaca LANGe-Bertalot et A. Fuhrmann sp. nov. (Figs 25-33 LM, 112a-b SEM external view) \\ Diagnosis}

Valvae omnes stricte lineari-ellipticae apicibus late rotundatis. Longitudo 12-16 $\mu \mathrm{m}$, latitudo 5-6.6 $\mu \mathrm{m}$. Ratio longitudo/latitudo 2.4-2.7. Raphe filiformis distincte recta apparens. Area axialis anguste linearis, circiter 0.7-1.0 $\mu \mathrm{m}$, interrupta nodulo centrali, area centralis circum nodulum non formata. Area canalium zonam comparate angustissime linearem formans punctis indistincte apicaliter ordinatis signata. Striae transapicales in media parte valvae parum radiantes tum leviter ad modice denique fortius radiantes usque sub apices, 16-18 in $10 \mu \mathrm{m}$. Aspectus ultramicroscopicus externus vide Figs 112a-b. A Diploneis modica HustedT 1945 differt areolis triseriatis in partibus marginalibus faciei et limbis valvae (aspectus microscopio electronico). Satis differt ab alteris speciebus plus minusve comparabilibus complexu omnium signorum typicorum particulariter a Diploneis puella (SchumANN) Cleve quoad protologium etiam D. puella sensu Mölder \& TyNNI aequaliter sensu EHRLiCH etiam quoad conceptiones differentes auctorum diversorum (vide infra).

Holotype (designated here): Slide G.H. S-3351 in Coll. Lange-Bertalot, Naturmuseum Senckenberg Frankfurt a.M. (FR), represented by Fig. 29.

Type locality: "Mainflinger See", a large pond in a gravel pit, on stones. Mainflingen, near Seligenstadt, Germany, Transect no. 2; leg. G. Hofmann 2.8.2014.

Etymology: The Latin adjective modicahassiaca refers to the type location in the German state of Hesse, modica in Latin means unpretentious.

\section{Description}

Valves strictly linear-elliptical with broadly rounded apices. Length 12-16 $\mu \mathrm{m}$, breadth 5-6.6 $\mu \mathrm{m}$. Lengthto-breadth ratio 2.4-2.7. Raphe filiform, straight with inconspicuous central and distal ends. Depressions parallel to the raphe are barely recognizable. Axial area very narrow, linear. A central area is not separated, except for the approximately square or sometimes very weakly constricted central nodule. Zone of the longitudinal canal system is by comparison extremely narrow; canal perforation is hard to differentiate from the transapical striae. Striae weakly radiate proxima- 
1ly, becoming moderately radiate towards and strongly radiate near the apices; $16-18$ in $10 \mu \mathrm{m}$. Areolae are not discernible. SEM external view see Figs 112a-b. Raphe slit almost straight but with shortly bent, not depressed central ends and slightly deflected distal ends. Axial area ca. $0.7-1.0 \mu \mathrm{m}$ broad, defined by single or obliquely paired small cribra consisting of four or five poroids. The adjacent striae are biseriate, becoming broader and distinctly triseriate closer to the valve face margins and onto the mantle. Each cribrum is composed of mostly four, sometimes five poroids; some cribra appear to be reduced to less than four poroids. The density of the areolae, pluriseriate and arranged in opposition, is very high compared to other cribrate Diploneis taxa except for D. modica, approximately 50 in $10 \mu \mathrm{m}$.

\section{Distribution and ecology}

As yet only observed from the type location. This is a gravel pit filled with ground water after exploitation. It is situated in the River Main valley close to Seligenstadt, not far from Frankfurt. The taxon is quite rare in the location and was found in a diatom assemblage of more than 100 taxa in a single sample, including several other Diploneis species, i.e. D. calcilacustris, D. elliptica, D. petersenii, D. minuta. The water is moderately alkaline with a medium conductivity, oligosaprobic and eutrophic.

\section{Taxonomical comments}

A somewhat resembling, undescribed population has recently been observed by us in Lake Baikal, Siberia (unpublished data). What makes D. modicahassiaca (as well as D. modica, but see below) so particular is the combination of, first, extremely narrow apical canals with, second, the small size of the cribra, each composed of two to four, rarely five poroids, and arranged triseriately (biseriately in D. modica) in the submarginal parts of the valve face and mantle. Moreover, the density of the striae areolae (as opposed to the canal areolae), ca. 50 in $10 \mu \mathrm{m}$, is much higher than in any other known Diploneis species with cribrate areolae, including the ones here described as new. We also point out that the comparatively small cell size with a length-to-breadth ratio of 2.4-2.7 already distinguishes D.modicahassiaca from $D$. puella both in the original sense of Schumann as well as according to the concepts of other authors.

The most resembling taxon is D. modica HusTEDT 1945, described from the "Ancient Lakes" Ohrid and Prespa, The Balkans, now belonging to Albania and Macedonia. Krammer \& Lange-Bertalot (1986) report and illustrate few specimens from two other locations in Austria, Namlos in Tyrol, and Lunz in the north-eastern Alps, both with questionable identification. Levkov et al. (2007), plate 124, contains the first SEM images from Lake Ohrid, but neither these nor their LM images represent $D$. modica, as they observe in their later work on Diploneis in Lake Ohrid (2013, p. 258). The latter publication includes a diagnosis with four LM and two SEM photographs of the true D. modica from Lake Ohrid. The metric data conform approximately to $D$. modicahassiaca but the remark that "the striae are biseriate, and each alveolus opens externally in groups (3-4) of small and rounded pores, 50 in $10 \mu \mathrm{m}$ " suggests that a trifurcation of alveoli towards the margin of the valve, characteristic for $D$. modicahassiaca, is absent. This is confirmed by an inspection of fig. 150 where such triseriate arrangement between broader virgae is not visible; cf. by contrast Figs $112 \mathrm{a}-\mathrm{b}$ showing $D$. modicahassiaca. D. modica has as yet never been observed in Germany or neighbouring countries, except for a doubtful identification from the Austrian Alps.

Diploneis nanofontanella LANGE-BERTALOT et A. Fuhrmann sp. nov. (Figs 58-63 LM, 64 SEM internal view)

Diagnosis differens versus Diploneis fontanella Lange-Bertalot in Werum \& Lange-Bertalot 2004

Synonym: Diploneis (? nov.) spec. in Lange-Bertalot \& Genkal 1999, figs 43: 5-10.

Valvae oblonge-ellipticae ad lineari-ellipticae apicibus obtuse rotundatis. Longitudo 14-24 (non 16-30) $\mu \mathrm{m}$, latitudo 5.5-6 (non 7-8.5) $\mu \mathrm{m}$. Ratio longitudo/ latitudo 3.3-4 (2.0-3.6 paulo differt). Raphe leviter lateralis recta (non differt). Area axialis angusta sed dilatata ad mediam versus (non differt). Area centralis comparate ampla, 2-2.5 $\mu \mathrm{m}$ lata, distincte separata $\mathrm{ab}$ area axiali, paene dimidium $=1 / 2$ latitudinis valvae extendens $($ non tertium $=1 / 3$ ). Appendices areae circularis et canales axiales non differunt. Striae transapicales fortius radiantes usque ad apices 19-22 (nec 16-18) in $10 \mu \mathrm{m}$. Aspectus ultramicroscopicus internus vide Fig. 64. Systema sternum cum canalibus axialibus dimidium latitudinis valvae extendens (vide area axialis, supra).

Holotype (designated here): Slide RUS-30 in Coll. Lange-Bertalot, Naturmuseum Senckenberg, Frankfurt (FR). Holotype shown in Fig. 60. Type material M5 in Coll. S. Genkal, Papanin Institute for Biology of Inland Waters, Russian Academy of Sciences, Borok. Type locality: Mestnyi Island, Yugorski-Shar Strait, Arctic Ocean, among bryophytes in a small river; leg. N.V. Vekhov, Sept. 1995.

Etymology: The epithet refers to the smaller size dimensions in comparison with the similar D. fontanella. Lat. nanus $=$ dwarf.

Differential description versus Diploneis fontanella LANGe-Bertalot in Werum \& LANGe-Bertalot 2004

Valves oblong-elliptical to linear-elliptical with bluntly rounded ends. Length 14-24 (versus 16-30) $\mu \mathrm{m}$, 
breadth 5.5-6 (not 7-8.5) $\mu \mathrm{m}$. Length-to-breadth ratio 3.3-4 (versus 2.0-3.6, is weakly different). Raphe appears slightly lateral, but this may be due to the internal depressions flanking the raphe sternum. Axial area narrow distally, expanding towards the middle of the valve (not different). Central area conspicuously large with respect to the narrowness of the valves, extending to about one-half of the valve breadth (not ca. one-third). Indistinct appendices of the central area and axial canals not different. Striae radiate throughout, 19-22 (not 16-18) in $10 \mu \mathrm{m}$. Areolae uniseriate, about 25 in $10 \mu \mathrm{m}$ (not different). - SEM internal view, see Fig. 64, cf. Also another SEM internal view in LANGEBertalot \& Genkal 1999, fig. 43: 10. The closing membranes covering the entire alveoli are uncorroded here, being distinctly narrower than the virgae. The canal system, together with the central nodule, extends to one-half of the valve breadth, as does the central area outside. The central part is clearly not set off due to almost evenly shortened striae (different from the shape in D. fontanella). The narrow depressions (furrows) on either side of the raphe sternum diverge at the central ends of the raphe slit (as opposed to being almost parallel in D. fontanella, cf. Werum \& LANGE-Bertalot 2004, fig. 74: 15).

Diploneis separanda Lange-Bertalot in WERUM \& LANGE-BeRtAlot 2004 differs mainly by a consistently smaller central area, broader valves, 6-7 $\mu \mathrm{m}$, and a higher areola density, approximately $30-35$ in 10 $\mu \mathrm{m}$.

\section{Distribution and ecology}

As yet only known from the type locality, a creek with pristine water which may be under the influence of strong winds from the Arctic Ocean. The species-rich diatom assemblage consists of oligotraphentic, acidophilous taxa associated with several alkaliphilous taxa tolerating a moderately high conductivity.

Diploneis oblongellopsis LANGE-BERTALOT et A. Fuhrmann sp. nov. (Figs 65-74 LM, 119-123 SEM external and internal views)

Synonyms: Diploneis oblongella (NäGeli) Cleve Euler sensu Lange-Bertalot \& Metzeltin 1996, figs 85: 8-9; Diploneis oblongella sensu Krammer \& LANGe-Bertalot 1986 pro parte, fig. 108: 10; Diploneis spec. Nr. 1 sensu Metzeltin \& Witкowski 1996, fig. 12: 7.

\section{Diagnosis}

Valvae ellipticae vel lineari-ellipticae apicibus late rotundatis. Longitudo 11.6-25 $\mu \mathrm{m}$, latitudo 5.7-7.8 $\mu \mathrm{m}$. Raphe filiformis recta extremis centralibus terminalibusque fere inconspicuis. Area axialis angusta conspicue linearis. Area centralis parva paene vacans vel plerumque quoad individua maiora apicaliter elliptica usque ad circiter quartum latitudinis valvae extendens. Zona canalium comparate angustissima distincte arcuata circum nodulum centralem. Striae transapicales fortius radiantes omnino, 20-24 in $10 \mu \mathrm{m}$. Areolae unaquisque discernendae omnes semper uniseriatae,
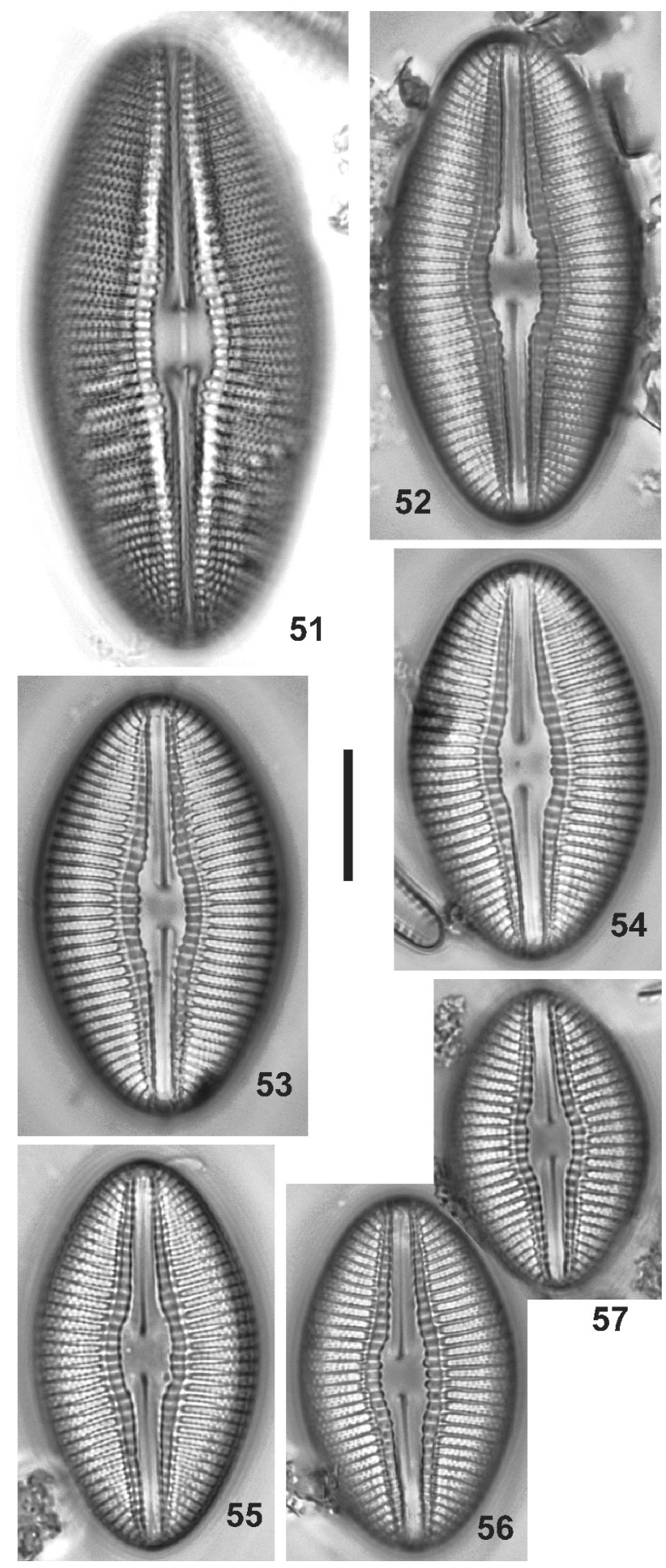

Figs 51-57. LM: Diploneis lusatica sp.nov., Spremberg water reservoir, Saxony, Germany, (53) designated holotype. Scale bar 10 $\mu \mathrm{m}$.

25-30 in $10 \mu \mathrm{m}$. Aspectus ultramicroscopicus externus internusque vide Figs 119-123. Extrema centralia externa curte uncinata. Extrema terminalia aliquid variabiliter formata sed omnia fere curte ad latus idem. Areolae striarum ubique stricte uniseriatae, 25-30 in $10 \mu \mathrm{m}$ confirmatae omnes occlusae externe cribris circularibus compositis 7-20 poris. Ita differt particulariter a $D$. praetermissa sed etiam omnibus speciebus generis cum cellulis parvis hic comparatis. 


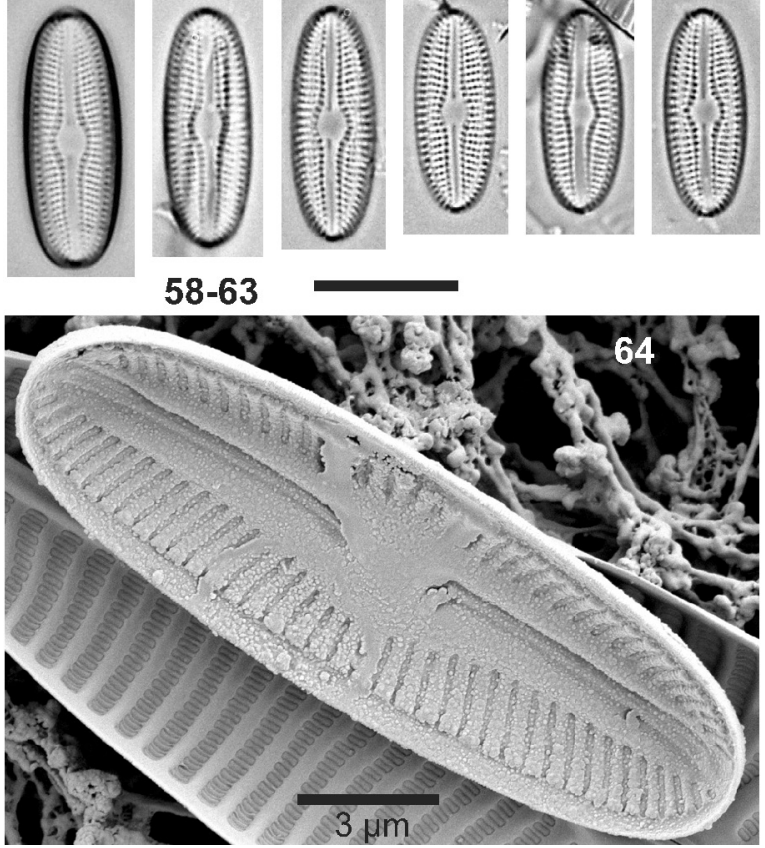

Figs 58-63. LM: Diploneis nanofontanella sp.nov., Mestnyi Island, Russian Arctic, (60) designated holotype. Scale bar $10 \mu \mathrm{m}$.

Fig. 64. SEM internal view: D. nanofontanella sp. nov., Mestnyi.
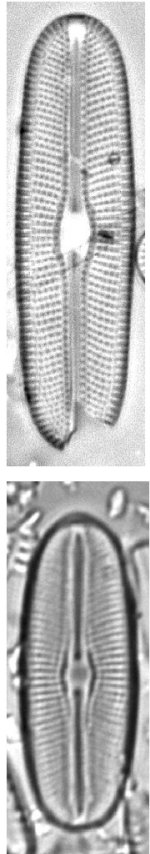
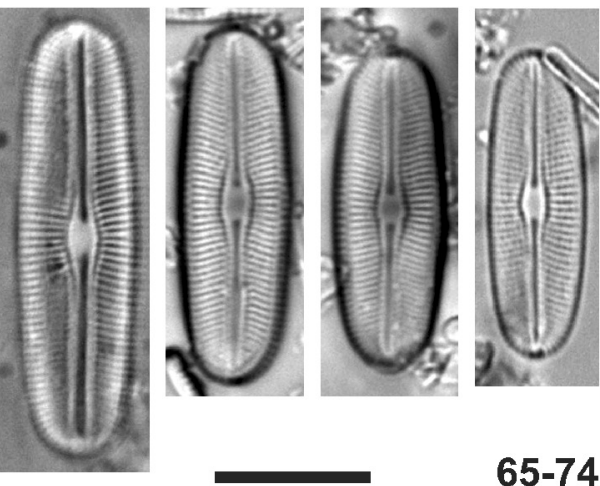

$65-74$
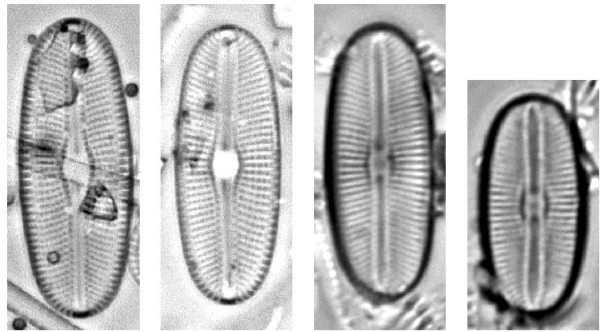

Figs 65-74. LM: Diploneis oblongellopsis sp.nov., Lake Laach, Eifel Mountains, Germany, (Figs 65, 71-72), Brunnsee, Upper Bavaria (Figs 66-70, 73-74), (65) designated holotype. Scale bar $10 \mu \mathrm{m}$.

Holotype (designated here): Slide Seen/251 in Coll. Lange-Bertalot, Naturmuseum Senckenberg, Frankfurt (FR), represented by Fig. 65 .

Type locality: Lake Laach, close to Maria Laach monastery, Eifel Mountains, West Germany. Sample LS 7, sediment $1-20 \mathrm{~cm}$, subfossil, likely ca. 100 years old (leg. Simone Illig, 2010.)
Etymology: The Latin-Greek epithet means "with the appearance of" $D$. oblongella auct. nonnull. It refers to Navicula oblongella Nägeli ex Kützing 1849 with the intention to remember in the future that ambiguous name (see comments).

\section{Description}

Valves elliptical to linear-elliptical with broadly rounded apices. Length 11.6-25 $\mu \mathrm{m}$, breadth 5.7-7.8 $\mu \mathrm{m}$. Raphe filiform, straight without recognizable peculiarities at central and distal ends. Axial area very narrow, strictly linear throughout, i.e. not extended proximally or narrowed distally. Central area barely present in smallest specimens, becoming larger and progressively set off from the axial area with elongation of cell cycle stages, shaped apically elliptical, extended to about a quarter of the valve breadth. $\mathrm{H}-$ shaped appendices absent. Axial canals very delicate, marked on either side by an apical line of single puncta which curve around the central nodule. These more strongly contrasted puncta are barely set off from the uniseriate areolae of the striae, 20-24 in $10 \mu \mathrm{m}$, which are conspicuously radiate throughout. The areolae are constantly more densely spaced than the striae and can still be resolved in appropriate focus without oblique lighting, 25-30 in $10 \mu \mathrm{m}$. SEM external view see Figs 119-120, 122-123. The relief of striae and virgae on valve face and mantle is extremely shallow irrespective of the amount of tilting. Thus the valve surface appears almost smooth, if the cribrate areolae are uncorroded (Figs 123). With higher magnification, more than $\times 10000$ (Fig 120), all cribra appear circular, consisting of ca. 7-20 single pores, gradually growing in diameter and number from the zone of canals towards and onto the mantle. After corrosion (Fig. 122) the areolae perforating the underlying canals are more contrasted, whence their position becomes easier recognizable, lying in a single apical line on either side of the sternum, weakly set off from the stria areolae. Slits of both raphe branches with unilaterally, shortly bent central and distal ends. The central ends are enclosed in short delicate raphe ribs and depressed into the valve surface. Internal view see Fig 121 after corrosion of all finer structures including occlusion membranes on the alveoli. If uncorroded, it may be very difficult to distinguish $D$. oblongellopsis from $D$. praetermissa since the uni- vs. biseriate areolae are then masked.

Differential description vs. D. praetermissa sp. nov. and other similar small-celled taxa

Unless both taxa can directly be compared in the same slide D. praetermissa (see below) is rather difficult to distinguish in LM view but very easy in SEM, mainly by regularly biseriate alternating areolae in considerably higher density. Moreover the profile of striae/virgae is higher; cribra in the canal zone are larger; distal raphe fissures are considerably longer. Such differentiating features concern likewise populations which 
are recorded under the problematic (because ambiguous) name $D$. oblongella; see the comments below on D. praetermissa. D. modica Hustedt has subparallel rather than more strongly radiate striae proximally and biseriate areolae just as D. fontanella or D. separanda (see elsewhere).

\section{Distribution and ecology}

We identified $D$. oblongellopsis in various strictly oligotrophic lakes and a slightly eutrophic one in central Europe, all rich in calcium carbonate content; a single specimen on the Arctic Bear Island (Svalbard); individual-rich on Gotland Island, the Baltic Sea, Sweden. The taxon should be wider distributed but is not easily separated from resembling taxa in LM. Quite often associated with $D$. separanda and D. praetermissa nov. sp.

\section{Taxonomical comments}

The current and historical concepts of D. oblongella are unsatisfactory because ambiguous. What are we to do with such a "catch all" taxon? Because there is no illustration of the basionym Navicula oblongella NäGELI ex KÜTZING it is not possible to designate a lectotype with ensuing epitypification. We would have to wait until an appropriate specimen may be found in Nägeli's original sample from Zurich, Switzerland. In a later second hand "type slide" (prepared from original type material) we could not find any specimen that would answer to the extremely poor protologue given by KütZING 1849 (see Werum \& LANGe-BerTALOT 2014, p. 145). The first to present an illustration of Nägeli's taxon was Grunow in Van Heurck (1880-85). The origin of the depicted specimen is unknown. It is $13.5 \mu \mathrm{m}$ long, $6 \mu \mathrm{m}$ broad, ca. 18.5 striae with roughly 25 puncta in $10 \mu \mathrm{m}$. However, even Grunow may have had no well-defined concept. In the text part of VAN Heurck (1885) where both authors are responsible with regard to taxonomical decisions, Grunow ends up with a diagnosis: $20 \mu \mathrm{m}$ long, $7.5 \mu \mathrm{m}$ broad, ca. 16 striae in $10 \mu \mathrm{m}$ with reference to Type de Synopsis no. 108, Oxford, England. Patrick \& Reimer (1966, fig. 38: 8) made a line drawing of a specimen from CLEVE \& MöLler exsiccate no. 139 which likewise has been authorized by Grunow: it is $30 \mu \mathrm{m}$ long, $11 \mu \mathrm{m}$ broad, 14-15 striae and ca. 18 puncta in $10 \mu \mathrm{m}$. Clearly this is too wide a spectrum for one and the same species. Even wider is the concept of PATRICK \& REIMER, as expressed in their diagnosis: 10-100 $\mu \mathrm{m}$ long, 6-35 $\mu \mathrm{m}$ broad, 10-19 striae and 13-20 areolae in $10 \mu \mathrm{m}$ - all these data concerning $D$. oblongella, including an allegedly younger homonym, D. ovalis (HiLSE) P.T. Cleve. From a modern taxonomical point of view, such a concept is untenable. As it happens, the basionym of D. ovalis (Hilse) P.T. Cleve, Pinnularia ovalis Hilse, has proved to be a different, large-celled taxon with a different structural pattern (LANGE-BERTALOT \& REICHARDT 2000). The consequence of such an extremely
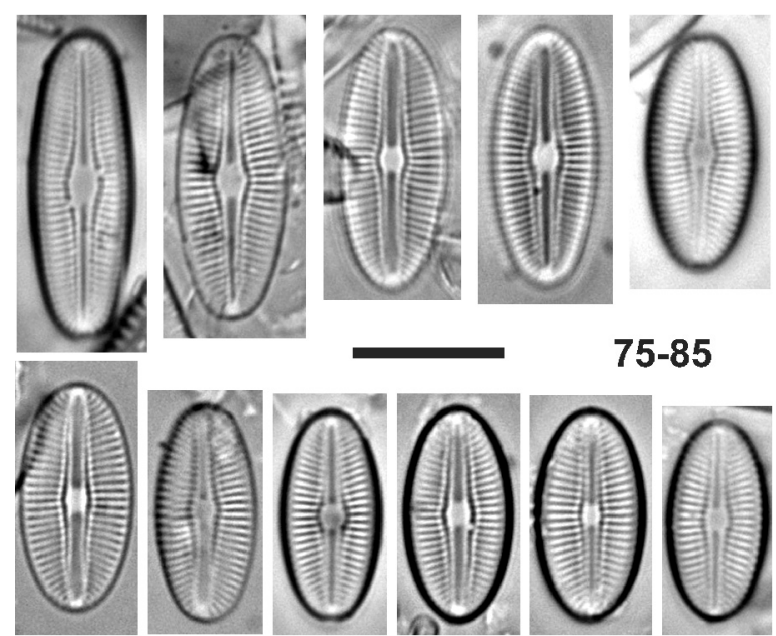

Figs 75-85. LM: Diploneis tirolensis sp.nov., Weissensee, (78) designated holotype. Scale bar $10 \mu \mathrm{m}$.

extended concept is displayed in FogED (1977, p. 50, figs 17: 1-6) where all specimens are taken to belong to the same species: figs $1-3$ and 6 are identified as $D$. ovalis var. ovalis, figs 4 and 5 are var. oblongella. From the present, more critical point of view, four distinct species are shown: Fig. 1 is D. krammeri, a taxon frequently mistaken for D. ovalis in the past (see LANGEBertalot \& Reichardt 2000); figs 2,3,6 are closely related to D. elliptica (see photographs of type specimens in Lange-Bertalot \& Reichardt 2000); fig. 4 is D. fontanella; fig. 5 belongs to D. oblongellopsis, the stria density being counted with 23-24 (not erroneously $16-17)$ in $10 \mu \mathrm{m}$.

Diploneis parahinziae Lange-Bertalot, A. FuhrMANN et H. Ringel sp. nov. (Figs 86-92 LM, 126-129 SEM external and internal views)

Diagnosis differens versus Diploneis hinziae sp. nov. (vide supra)

Differt proprie densitate superiori striarum 12.5-14 (nec 11-12.5) in $10 \mu \mathrm{m}$. Areolae $15-20$ in $10 \mu \mathrm{m}$ parum differunt sed extra zonam canalium regulariter biseriatae et prope marginem limbi triseriatae ordinatae (nec uniseriatae et in limbo biseriatae). Valvae omnes praesentes in loco typico 17-26 $\mu \mathrm{m}$ longae (nec usque ad 50) et 11-14 $\mu \mathrm{m}$ latae (nec usque ad 18).

Holotype (designated here): Slide Am-N-130 in Coll. Lange-Bertalot, Naturmuseum Senckenberg, Frankfurt (FR), represented by Fig. 87.

Type locality: Everglades National Park (Florida, U.S.A.), 20 miles west of Miami, boat landing close to National Road No. 41, epiphytic on Lemnaceae, leg. Hubert Ringel, 17.11.2010.

Etymology: The prefix para in classical Greek means: beside of (a similar taxon; here: $D$. hinziae, see above).

\section{Description}

Valves elliptical to weakly linear-elliptical, ends 
bluntly rounded. Length 17-26 $\mu \mathrm{m}$, breadth 11-14 $\mu \mathrm{m}$. Length-to-breadth ratio 1.5-1.9. Raphe filiform, appearing almost straight or (mostly) deflected towards expanded central ends; distal ends indistinct. Axial area narrow with a parallel dark line on either side of the raphe indicating internal depressions along the sternum (which become visible by focusing). Central area elliptical, small, $1 / 6$ to $1 / 4$ of the valve breadth. $\mathrm{H}-$-shaped appendices are not developed. Sector of internal canals very narrow with canal areolae appearing barely set off from the other areolae. Striae weakly radiate in proximal parts, becoming rather strongly radiate close to the ends, $12.5-14$ in $10 \mu \mathrm{m}$. Areolae appear uniseriate, becoming indistinctly pluriseriate in marginal parts, $15-20$ in $10 \mu \mathrm{m}$.

SEM external view see Figs 126 with intact cribra and Fig. 127 with corroded cribra. Raphe with short, crochet-hook shaped central ends and longer distal fissures which are bent towards the mantle, all to the same side. The valve surface is not completely domed but flattened in the central part. One or two single areolae with circular cribra are arranged above the underlying canal system, somewhat separated from the biseriate areolae at first in apical juxtaposition, then becoming gradually alternating. Finally, on the valve mantle, areolae become smaller and triseriate between narrow virgae. Close to the margin a small open pore in the middle between two virgae becomes visible, mainly in distal parts (Fig. 128). Internal view see Fig. 129. Raphe canal system and central nodule do not differ from many other freshwater Diploneis species, particularly not from $D$. hinziae. This concerns likewise uncorroded occluding membranes covering the entire alveoli and masking the arrangement of areolae. Virgae and striae are about equally broad - in contrast to the proportions in external valve view. An internal view with corroded occlusion membranes could not be found.

Differential description vs. $D$. hinziae sp. nov. (see above) $L M$ view

Largest cell cycle stages of the population from Florida (others are as yet not known) do not exceed a valve length of 26 (vs. 23-50) $\mu \mathrm{m}$ and a valve breadth of 14 (vs.
$15-18) \mu \mathrm{m}$. Stria density is $12.5-14$ (vs. 11-12.5) in $10 \mu \mathrm{m}$, areola density $15-20$ in $10 \mu \mathrm{m}$. SEM view: The biseriate striae become triseriate in the valve mantle, whereas striae continue clearly biseriate throughout in D. hinziae (see LM and SEM Fig. 114 of internal view.)

\section{Distribution and ecology}

As yet only known from the Everglades, Florida. This is a border area between two biogeographic realms, the southern Holarctic and the Neo-Subtropics. The diatom assemblage in the type locality is dominated by acidophilous or acidobiontic taxa, including various Eunotia spp. indicating dystrophic conditions.

\section{Taxonomical comments}

This Florida population is ranked as a species independent of the resembling $D$. hinziae based on several distinguishing morphological characteristics. In addition, the autecology, living in dystrophic water, and the biogeographic occurrence in a subtropical border region contribute to justifying this decision. For a possibly different taxonomical ranking in the future more sample populations of both taxa will be needed in order to carry out molecular genetic or population biological investigations (e.g. testing for cross-breeding).

Diploneis praetermissa LANGe-Bertalot et A. FuHRMANN sp. nov. (Figs 34-40 LM, 134ab-138 SEM external and internal views)

Diagnosis differens versus Diploneis separanda Lange-Bertalot in Werum \& Lange-Bertalot 2004

Lineamenta valvarum simillima et dimensiones simillimae, ellipticae ad lineari-ellipticae apicibus late rotundatis. Longitudo 8-25 $\mu \mathrm{m}$, latitudo 5.5-7.8 $\mu \mathrm{m}$. Raphe linearis recta extremis centralibus curtissime curvatis et extremis terminalibus comparate longe uncinatis ad latus idem. Area axialis angustissima linearis vix (nec distincte) dilatata versus mediam valvae. Area centralis minima parum expansa et separata $a b$ area axiali, appendices in forma litterae $\mathrm{H}$ nullae. Canales axiales prope raphem delicatissimi angustissimi parum arcuati circum nodulum centralem. Areolae externe cribratae hic uniseriatae distincte separatae ab striis transapi-
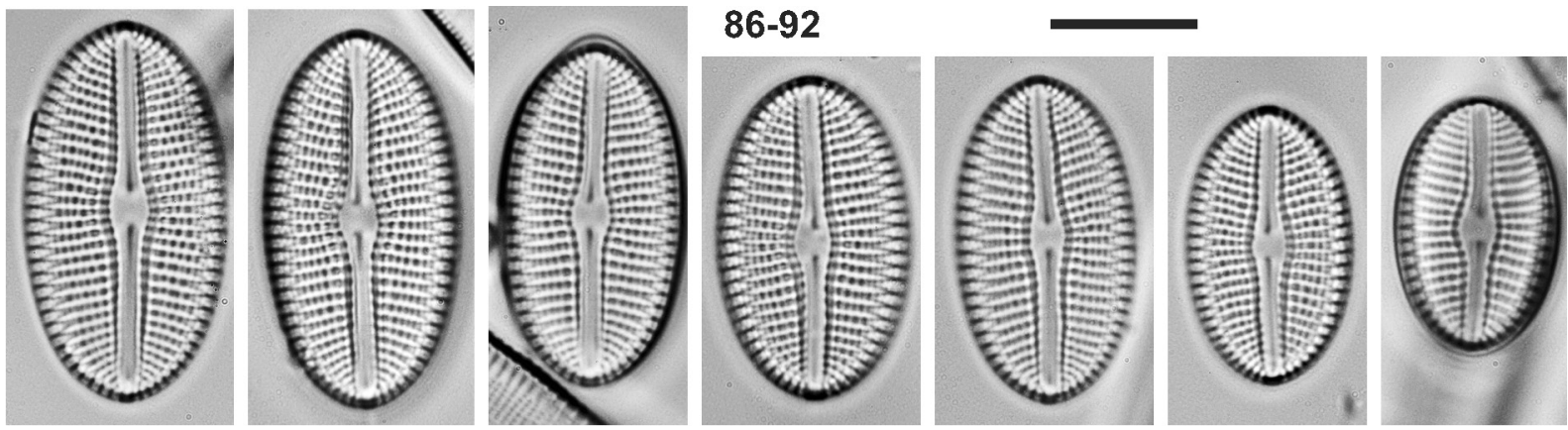

Figs 86-92. LM: Diploneis parahinziae sp. nov., Everglades, Florida, (87) designated holotype. Scale bar $10 \mu \mathrm{m}$. 

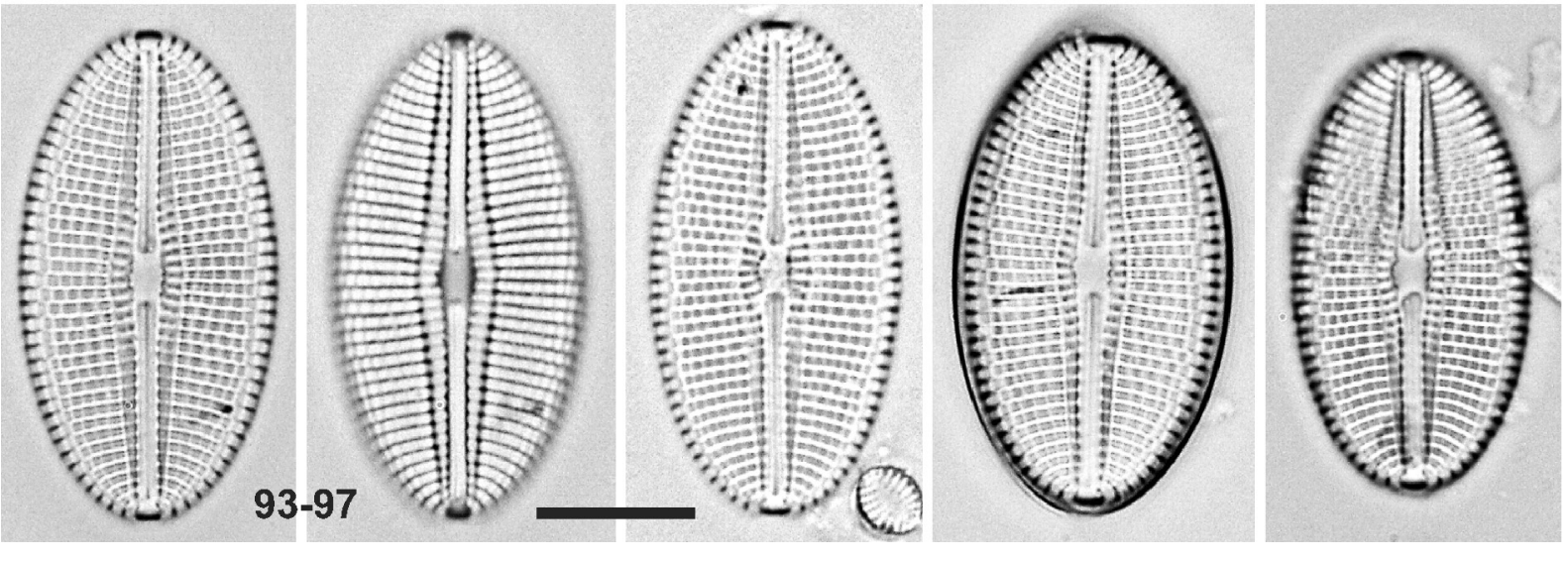

Figs 93-97. LM: Diploneis tundra sp. nov., Mestnyi, (93) designated holotype. Scale bar $10 \mu \mathrm{m}$.
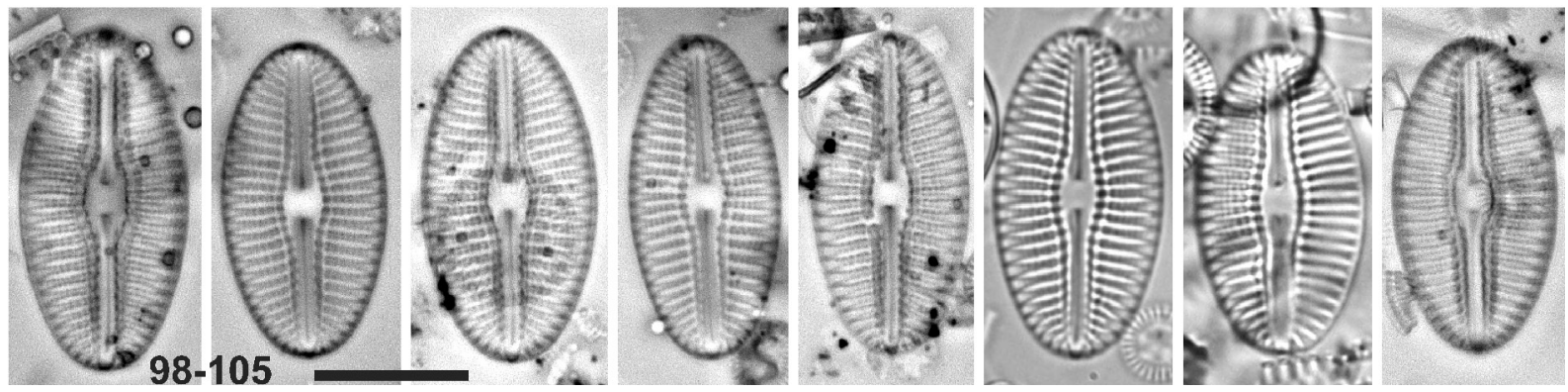

Figs 98-105. LM: Diploneis puellafallax sp. nov., Laach, (101) designated holotype. Scale bar $10 \mu \mathrm{m}$.

calibus in medio leviter tum modice radiantibus et ibi regulariter biseriatis (vide Figs 134b,136) inter virgas transapicales, $17-19$ in $10 \mu \mathrm{m}$. Areolae alternantes, 32-35 in $10 \mu \mathrm{m}$, numquam discernendae microscopio photonico ita differt a $D$. separanda ubi striae biseriatae cum areolis oppositis (nec alternantibus) solum prope limbos usque ad margines (vide WERUM \& LANGE-BERTALOT 2004, figs 76: $15-16$ et 77: 3-5).

Differt ab alteris paucis speciebus plus minusve similibus in aquis dulcibus combinatione signorum typicorum quoad areas axiales centralesque et structuras ultramicroscopicas.

Holotype (designated here): Slide Eu-A 198 in Coll. Lange-Bertalot, Naturmuseum Senckenberg, Frankfurt (FR), represented by Fig. 39.

Type locality: Weissensee, a calcium-carbonate rich oligotrophic alpine lake, ca. $1050 \mathrm{~m}$ a.s.l., near Lermoos in Tyrol, Austria; leg. K. Külbs, Sept. 1982.

Etymology: Lat. praetermissus $=$ left out, overlooked.

\section{Differential description versus Diploneis separanda} LANGE-Bertalot in Werum \& LANGE-Bertalot 2004 Valves of both taxa hardly distinguishable as to size dimensions and outlines; elliptical to linear-elliptical with bluntly rounded apices. Length $8-25 \mu \mathrm{m}$, breadth 5.5-7.8 $\mu \mathrm{m}$. Raphe linear, straight, without remarkably modified central and distal endings (see below).
Axial area very narrow, linear, barely expanded and separated from the central area. $\mathrm{H}$-shaped appendices lacking. Axial canals delicate, very narrow (appearing comparatively less pronounced), canal areolae uniseriate, $17-19$ in $10 \mu \mathrm{m}$, as adjacent transapical striae. Puncta of the striae not discernible in light microscope. SEM, external and internal view, see Figs 134ab-138. External central raphe ends fish-hook shaped, whereas distal ends are longer bent off onto the mantle, all to the same side. The areolae above the internal canals on either side are particularly marked and appear slightly depressed into the valve surface, occluded by cribra typical for Diploneis. Number of stigmoids composing these cribra is high, ca. 20 (vs. in striae at most 8 per cribrum). The transapical striae, radiate, becoming less radiate in the centre, $17-19$ in $10 \mu \mathrm{m}$, are biseriate throughout (not uniseriate, becoming biseriate only near the mantle down to the valve margins). Regularly biseriate, alternating (not opposed) areolae, 32-35 in $10 \mu \mathrm{m}$, are comparatively small and barely discernible by LM observation (in contrast to the opposed ones in D. separanda).

\section{Distribution and ecology}

Insufficiently known, since as yet not distinguished from D. separanda or specimens recorded under the dubious taxon Diploneis oblongella (NäGELI ex Kützing 1849) Cleve-Euler 1922 or Diploneis ovalis 

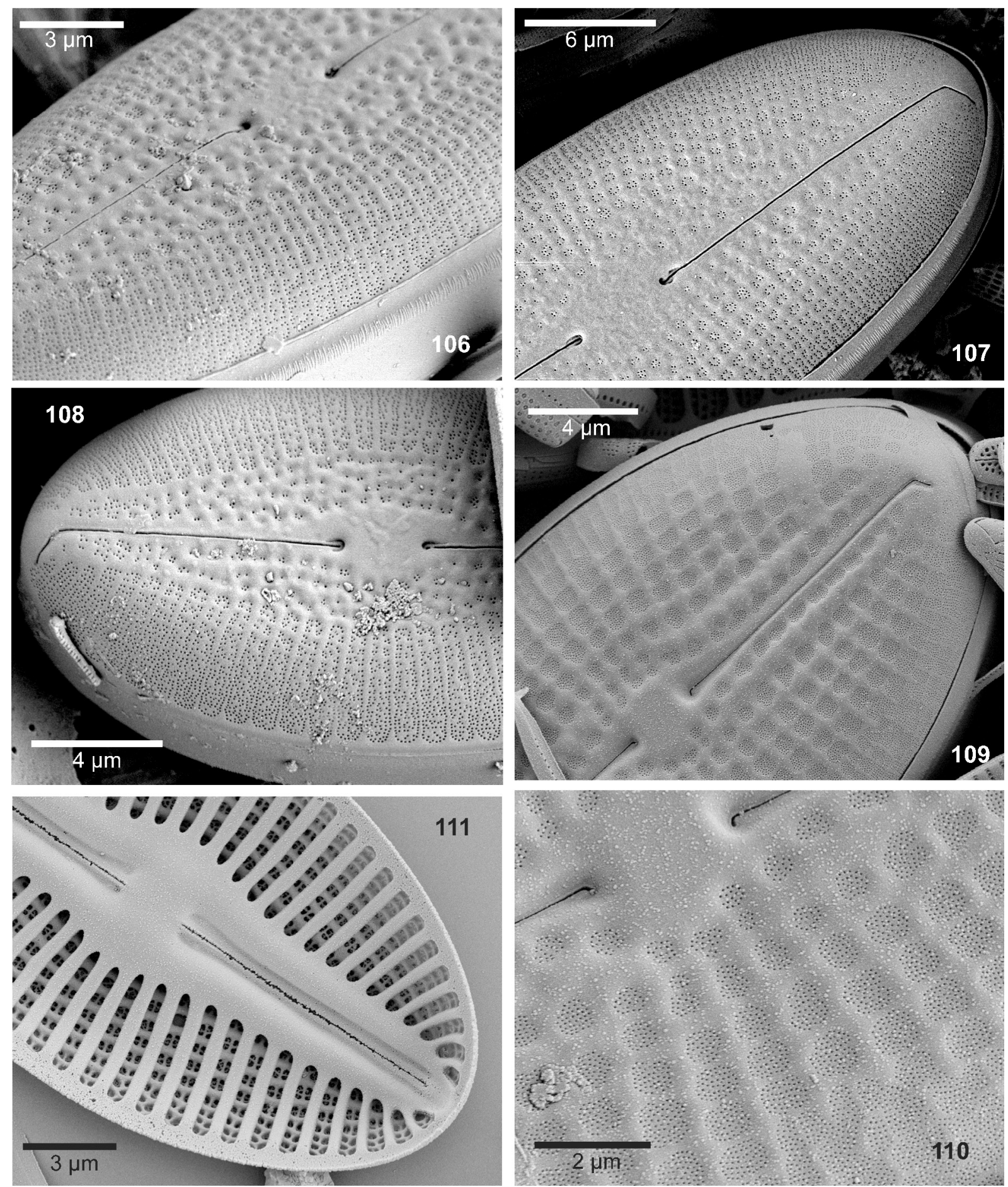

Figs 106-108. SEM external view: Diploneis abscondita sp. nov., Marbe. Striae uniseriate near the apical axis becoming biseriate near the valve margins onto the mantle. Areolae opposed, not alternating; (109-110) D. calcilacustris sp. nov., Bohinj. Fig. 111. SEM internal view: $D$. calcilacustris, Bohinj. 

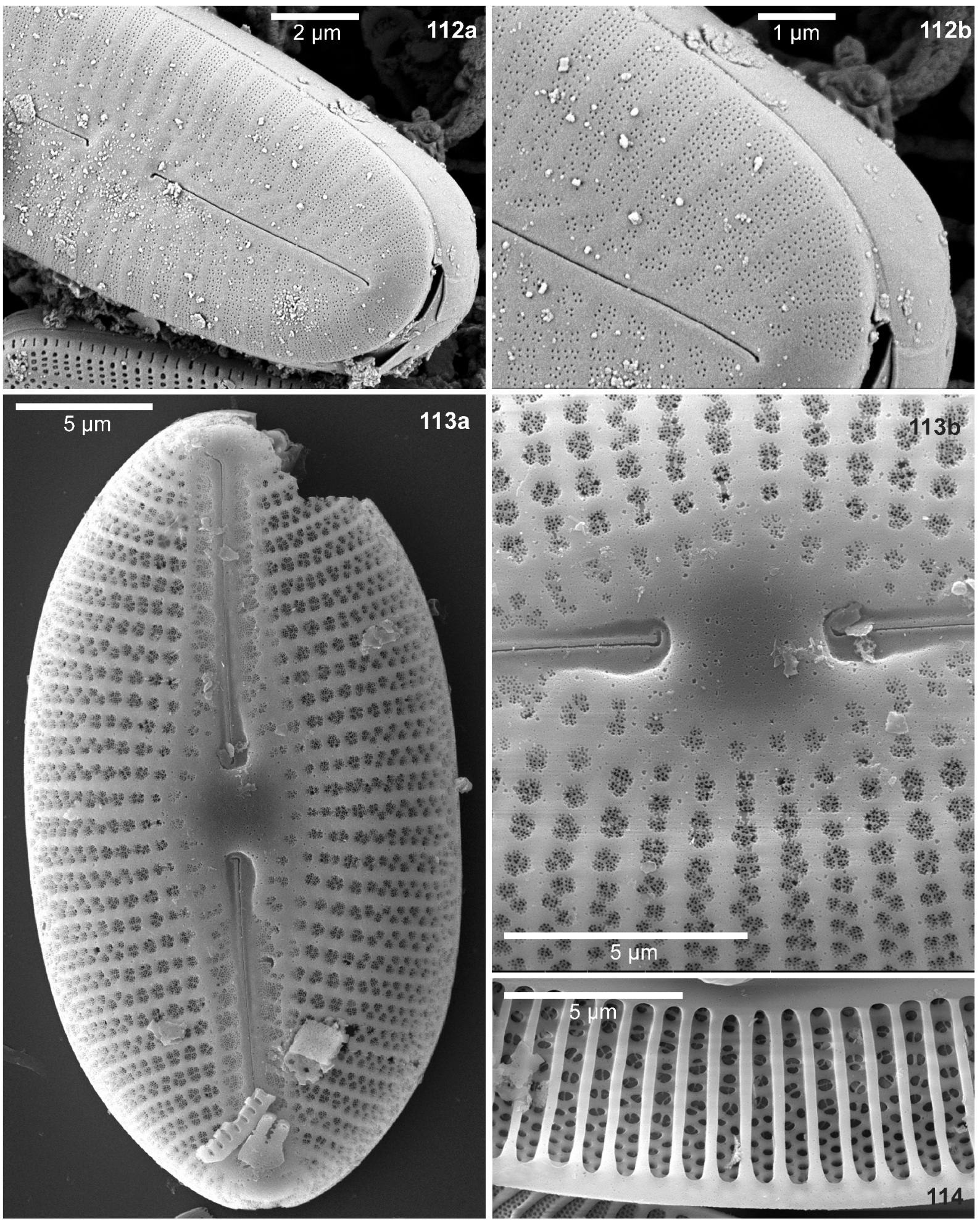

Figs 112a-b. SEM external view: Diploneis modicahassiaca sp. nov., Mainflingen. Figs 113a-b: SEM external view: D. hinziae sp. nov., Grialetschsee. Fig. 114. SEM internal view: D. hinziae, Grialetschsee. 

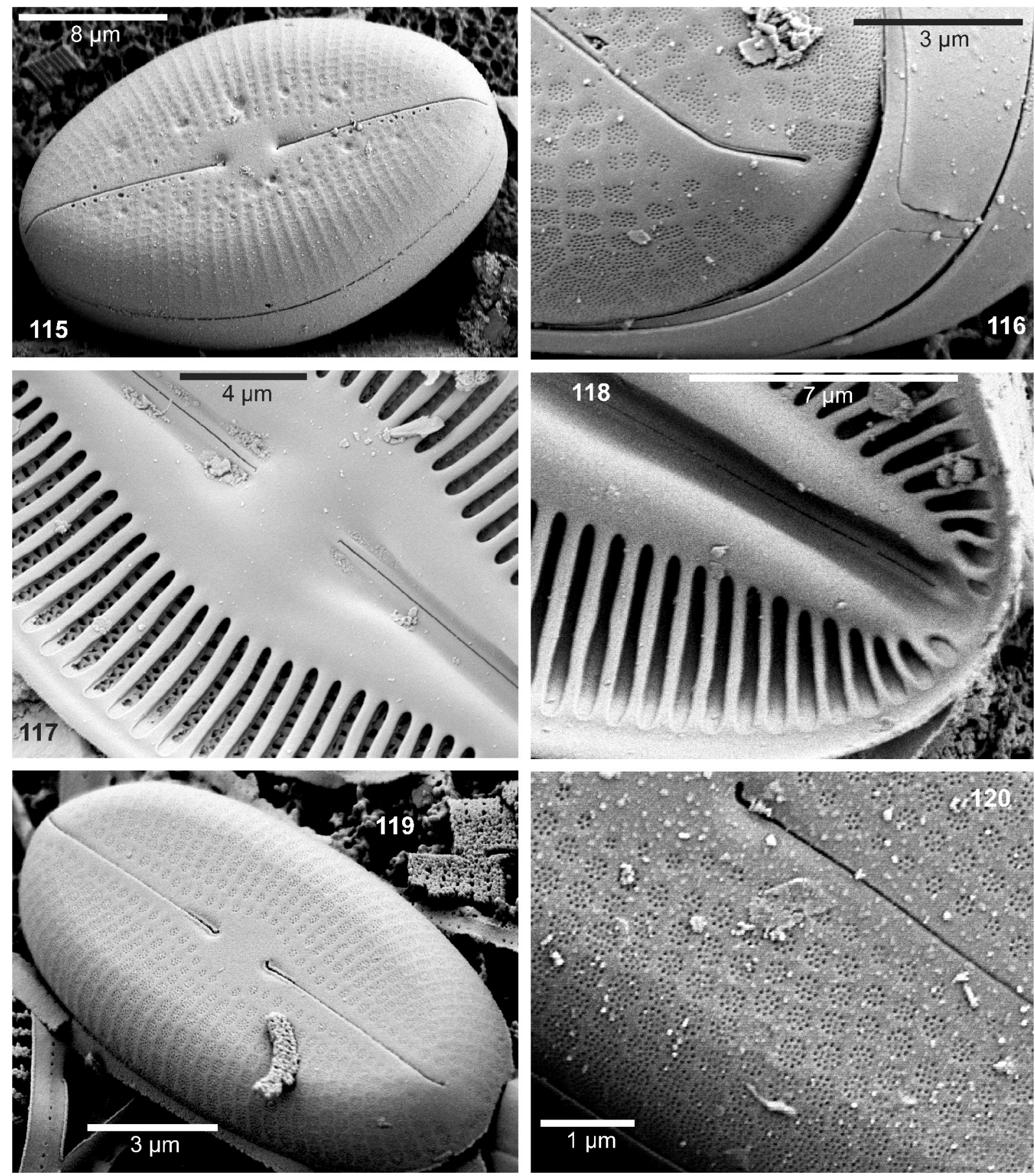

Figs 115-116. SEM external view: Diploneis lusatica sp. nov., Spremberg. Figs 117-118. SEM internal view: D. lusatica, Spremberg. Figs 119-120. SEM external view: D. oblongellopsis sp. nov., Laach (Fig. 119), Brunnsee (Fig. 120).

var. oblongella (NäGELI ex KÜTZING) P.T. Cleve 1894; see Werum \& Lange-Bertalot (2004, pp. 145f.). The type locality is oligotrophic with average conductivity. Other locations where $D$. praetermiss $a$ could be found are oligo- to slightly eutrophic but always oligosaprobic. Associated are predominantly oligotraphentic, calciphilous diatom taxa. In several lakes associated with D. separanda and D. oblongellopsis sp. nov.

\section{Comments}

Navicula oblongella NÄGELI in the sense of Kützing's protologue can hardly be considered as a synonym since the girdle view is described as broadly linear. By contrast Diploneis praetermissa and likewise $D$. separanda are very rarely found in the very narrow girdle view.

Another species appearing very similar in the light microscope is Diploneis modica Hustedt 1945, holotype from ancient Lake Ohrid (Macedonia,The 


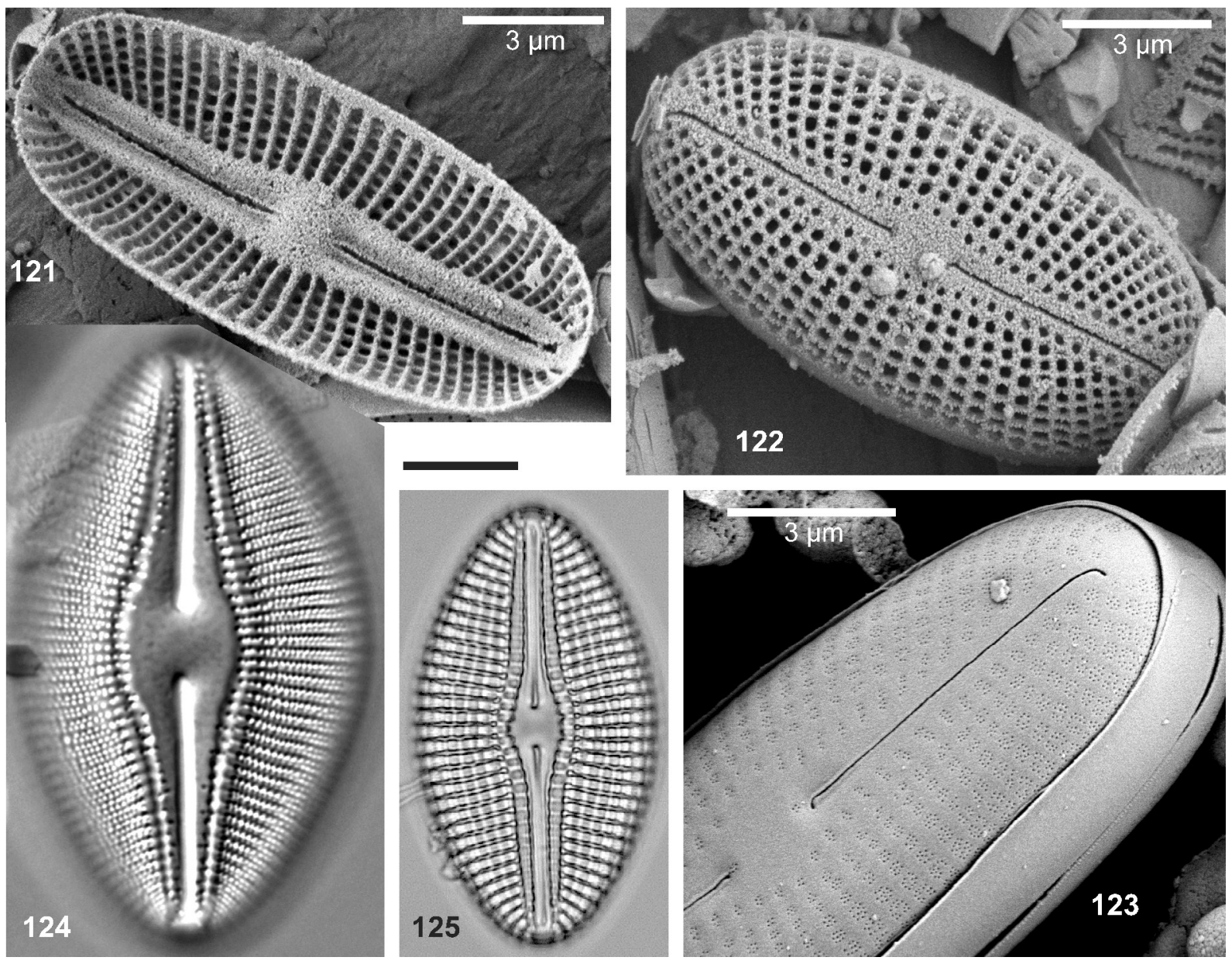

Fig. 121. SEM internal view: Diploneis oblongellopsis sp. nov., Brunnsee. Figs 122-123. SEM external view: D. oblongellopsis sp. nov., Brunnsee (Fig. 122, corroded cribra), Marbe (Fig. 123, intact cribra). Fig. 124. LM: D. dilatata stat. nov., from lectotype Tempère \& Peragallo, no. 104, Fall Mountain, Connecticut. Scale bar $10 \mu \mathrm{m}$. Fig. 125. LM: D. elliptica (Kützing) Cleve, Bohinj. Scale bar $10 \mu \mathrm{m}$.

Balkans), a second specimen documented from nearby Lake Prespa, looks quite similar in LM, like $D$. separanda. JovANOvsKa et al. (2013, figs 145-150) document some more specimens from Lake Ohrid with LM and SEM microscopy in comparison with the latter. The main difference in LM are less radiate striae in $D$. modica. In external SEM view $D$. modica is distinguished from $D$. praetermissa mainly by the very short terminal raphe fissures, more densely spaced areolae, ca. 50 in $10 \mu \mathrm{m}$ in external SEM view.

Diploneis puellafallax Lange-Bertalot et A. FunRMANN sp. nov. (Figs 98-105 LM, 130-133 SEM external and internal views)

Diagnosis differens versus Navicula puella ScHUMANN 1867

Valvae ellipticae vel plerumque lineari-ellipticae (nec stricte late ellipticae) apicibus late rotundatis. Longitudo $15-30 \mu \mathrm{m}$ (non 6.2-11.3 vel fortasse $15 \mu \mathrm{m}$ ), latitudo 9-14.5 $\mu \mathrm{m}$ (non 4.1-7.5 vel fortasse $10 \mu \mathrm{m}$ ). Ratio longitudo/latitudo 1.7-2.1 (non fere constanter circiter 1.5). Raphe filiformis recta extremis externis centralibus terminalibusque curte deflexis omnibus unilateraliter. Area axialis (alias depressiones internae parallelae ad raphem) angusta linearis. Area centralis parva plus minusve elliptica vel circularis. Canales apicales utrimque zonam anguste lanceolatam indistincte punctatam formantes. Striae transapicales comparate crassae apparentes proximaliter modice sub apices fortius radiales, 11-13 (nec 17-18) in $10 \mu \mathrm{m}$. Areolae alternantes biseriatae omnino, 22-26 in $10 \mu \mathrm{m}$. Aspectus ultramicroscopicus externus internusque vide Figs $130-133$.

Holotype (designated here): Slide Seen/251 in Coll. Lange-Bertalot, Naturmuseum Senckenberg, Frankfurt (FR), represented by Fig. 101.

Type locality: Lake Laach, close to Maria Laach monastery, Eifel Mountains, West Germany. Sample LS 7, sediment $1-20 \mathrm{~cm}$, subfossil, likely ca. 100 years old (leg. Simone Illig, 2010.)

Etymology: The false (Lat. fallax) Diploneis puella. In combination with "puella" it means the false girl or darling. 

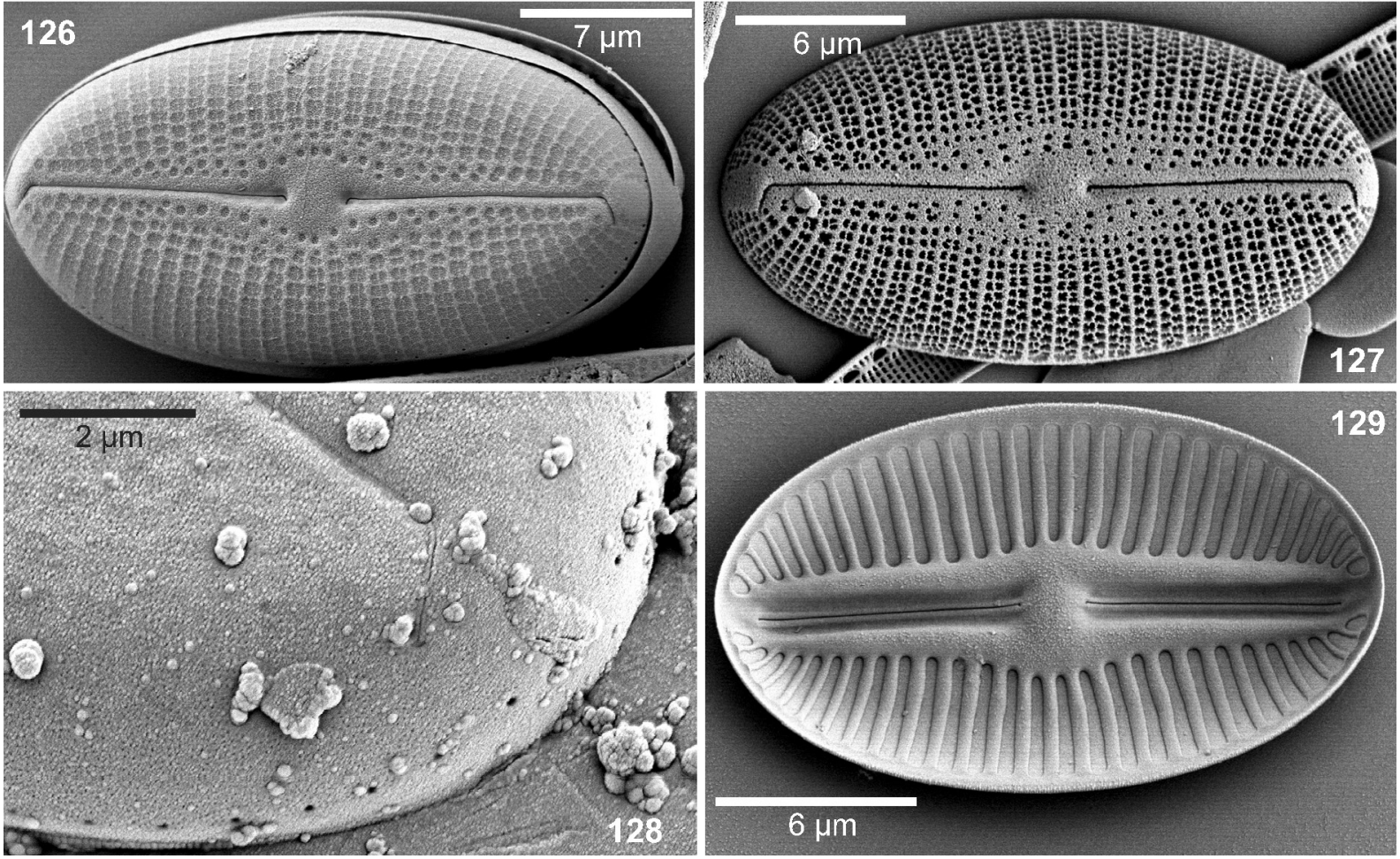

Figs 126-128. SEM external view: Diploneis parahinziae sp. nov., Everglades. Close to the margin small open pores in the middle between two virgae (Fig. 128). Fig. 129. SEM internal view: D. parahinziae, Everglades. All alveoli with intact occluding membranes.

\section{Description}

Valves elliptical or more often linear-elliptical with bluntly rounded apices. Length $15-30 \mu \mathrm{m}$, breadth 9-14.5 $\mu \mathrm{m}$. Length-to-breadth ratio 1.7-2.1. Raphe filiform, straight with slightly marked central ends and inconspicuous distal ends. Narrow depressions flanking the internal raphe slit. Axial area as a whole is very narrow, linear. Central area is very small, hardly expanded circularly or elliptically, without any recognizable $\mathrm{H}$-shaped appendices (horns). The internal longitudinal canals on either side are narrow, marked externally by a row of indistinct puncta. Transapical striae are radiate throughout, more strongly near the ends, appearing comparatively coarse, 11-13 in 10 $\mu \mathrm{m}$, being composed of two rows of opposed to alternating areolae, 22-26 in $10 \mu \mathrm{m}$. SEM external and internal view, see Figs 130-133. External view (Fig. 133) exhibits a slightly curved raphe slit with shortly bent central ends depressed into the valve surface and a small, gently deflected distal groove. A differentiated terminal fissure is lacking. Cribra above underlying canals appear somewhat irregularly distributed, uni- to biseriate; cribra of adjacent striae appear more closely condensed, biseriate to finally confluent onto the barely differentiated mantles. Internal view with uncorroded closing membranes see Fig. 132, after corrosion see Figs. 130-131. The relief of canals, central nodule and virgae is rather high. The raphe slit lying in a narrow, particular raphe rib is separated from the canals by depressions which appear as dark lines in LM view. In open alveoli the areolae are arranged opposed biseriate closer to the canals, becoming gradually alternating and finally even triseriate at valve margins.

\section{Differential description}

Diploneis puella (Schumann) Cleve does possibly not belong to Diploneis but to some other small-celled naviculoid genus. The given diagnostic features in the protologue are: broadly elliptical outline, length 6.18 $11.3 \mu \mathrm{m}$, breadth $4.1-7.5 \mu \mathrm{m}$ (measurements converted from Paris lines), length-to-breadth ratio 1.5 consistently, $17-18$ radiate striae in $10 \mu \mathrm{m}$, the longest of them being composed of five granules (puncta) which are difficult to recognize with the optics from 1867. Numerous specimens were observed in the Pissa River near Königsberg, East Prussia, and in the Baltic Sea at the port of Pillau (now Baltijsk). It is not yet clear whether Navicula puella Schumann and Diploneis puella (Schumann) Cleve sensu Mölder \& Tynni (1973), fig. 3: 33 , are identical. The specimen depicted there is ca. $15 \mu \mathrm{m}$ long, $10 \mu \mathrm{m}$ broad, length-to-breadth ratio is thus 1.5 , striae 18 in $10 \mu \mathrm{m}$. This may fit roughly the diagnosis of the protologue. However, puncta (granula composing the striae) are not detectable. Moreover, the narrow striae in the photograph do not seem to be biseriate as in D. puellafallax sp. nov. Thus neither the original concept nor the one of MÖLDER \& TYNNI conform to the concept found in Krammer \& Lange-Bertalot (1986, figs 109: 15-16). This concerns likewise D. puella sensu EнRLich (1995), figs 18: 7-9, from more or 

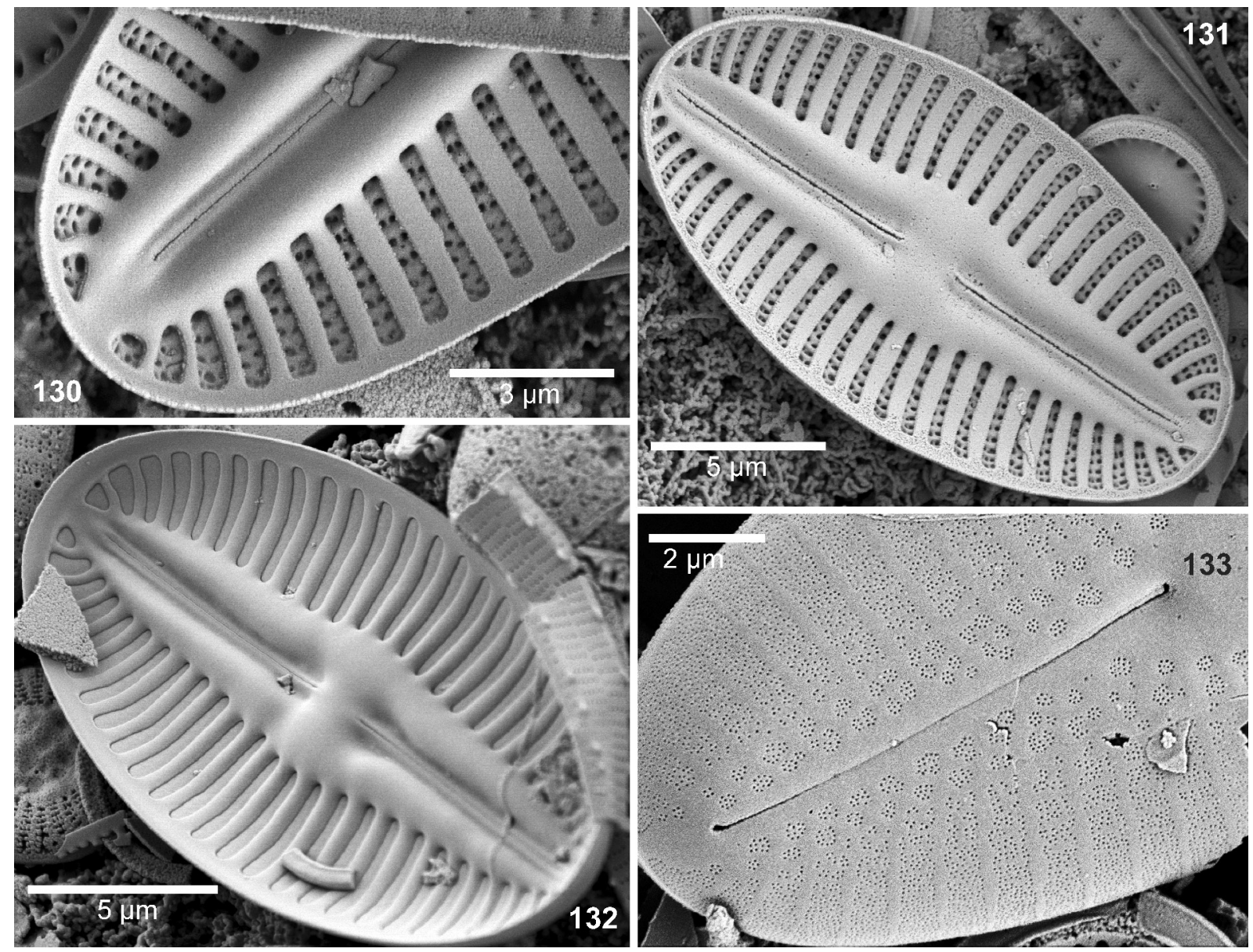

Figs 130-132. SEM internal view: Diploneis puellafallax sp. nov., Laach. Valves with open (130-131) and occluded (132) biseriate areolae. Note (133) shortly bent central and very weakly deflected distal raphe ends; compare Figs 134-136. Fig. 133. SEM external view: D. puellafallax, Laach.

less brackish inland waters in Israel. It resembles widely D. puella sensu MöLDER \& TYNNi and approximates Schumann's protologue. $D$. vetusa Johanovska et al. (2013) from ancient Lake Ohrid (the Balkans), known as resort for numerous endemic diatoms and other organisms, differs mainly by a smaller central area or nodule, and a lower areola-density of 15-20 areolae in 10 $\mu \mathrm{m}$; the distal raphe ends externally are more strongly deflected into a less expanded terminal pore.

\section{Distribution and ecology}

Uncommon in Europe but abundant in places. The freshwater of the type locality has been rated as mesotrophic on the basis of the diatom assemblage composed of many taxa that are assessed as oligotraphentic and others that are tolerant to moderately eutrophic but oligosaprobic conditions. Up to recently the specific conductivity of the lake was neither low nor high but “medium", probably about 200-500 $\mu$ S.cm ${ }^{-1}$.

\section{Comments}

Diploneis puella sensu Germain (1981) does neither belong to $D$. puella sensu MöLder \& TYNNI nor to $\mathrm{Na}$ vicula puella in the original sense. But the three spe- cimens illustrated in figs 55: 12-14 represent at least two different other taxa, $D$. fontanella (fig. 12) and $D$. separanda (fig. 13 and possibly also fig. 14). D. puella sensu Patrick \& Reimer (1966, fig. 38: 9) from Arizona is another taxon not conforming to the concepts mentioned above. BEY \& ECTOR (2013) show LM microphotographs of D. ovalis sensu Germain (1981) as an unknown taxon from a river in the Rhône-Alpes region of France. This one appears more closely related to $D$. puellafallax than to $D$. ovalis.

Diploneis tirolensis Lange-Bertalot sp. nov. (Figs 75-85 LM, 139-141 SEM external and internal views)

\section{Diagnosis}

Valvae ellipticae vel lineari-ellipticae quoad cellulas maximas apicibus late rotundatis. Longitudo 9-21 $\mu \mathrm{m}$, latitudo 6.4-7 $\mu \mathrm{m}$. Ratio longitudo/latitudo 1.6-3.0. Raphe filiformis recta extremis centralibus terminalibusque inconspicuis. Area axialis angustissima linearis aliquid expansa ad mediam. Area centralis distincte separata particulariter quoad individua maiora cum nodulo centrali circularis apparens vel apicaliter elliptica extendens minus quam quartum latitudinis valvae. 


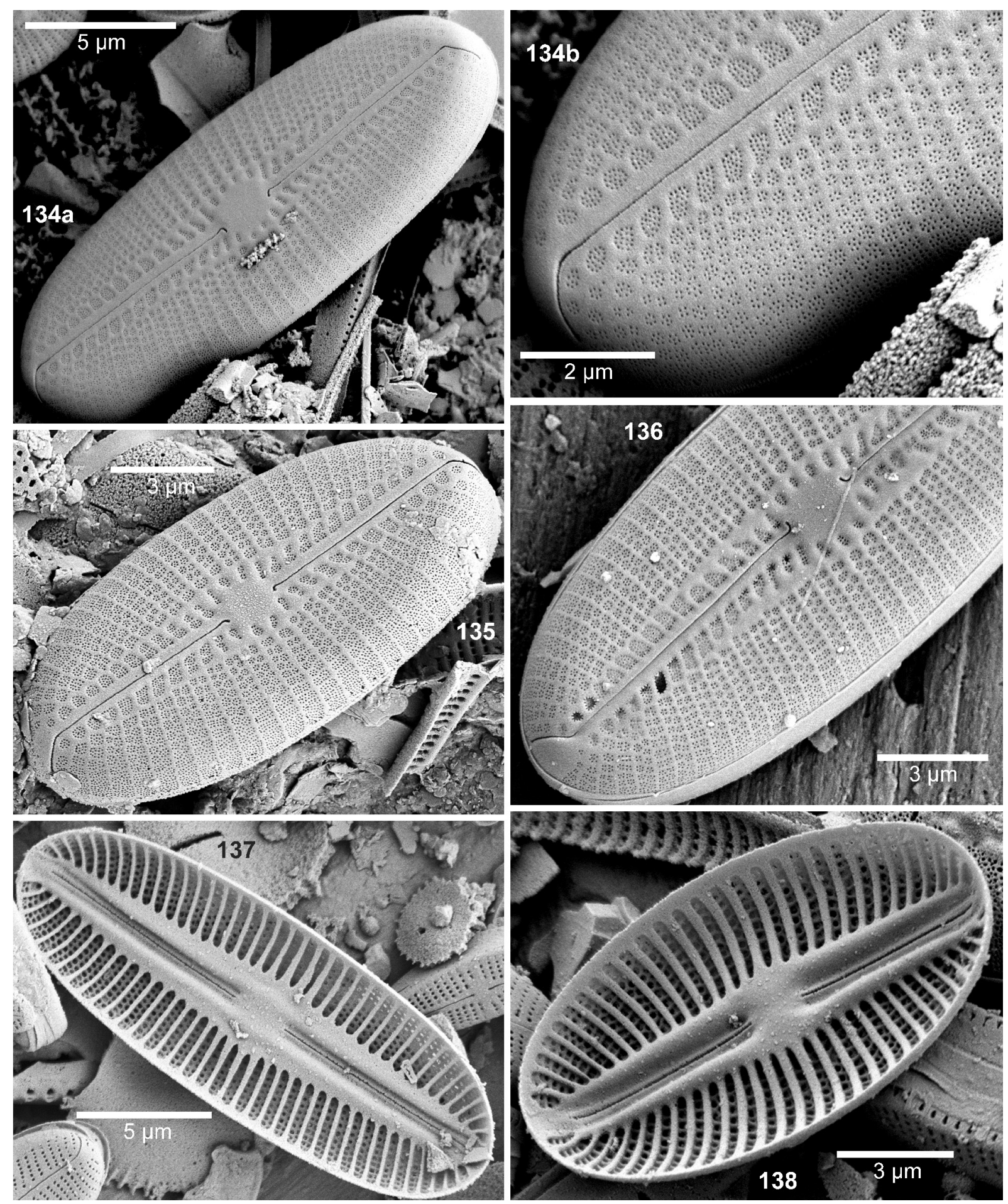

Figs 134ab-136. SEM external view: Diploneis praetermissa sp. nov., Laach (Figs 134ab, same specimen), Lustsee, Upper Bavaria, Osterseen near Iffeldorf (Fig. 135), Weissensee (Fig. 136). Note (particularly 136) the long distal raphe fissures, present consistently, distinguishing this taxon from all more or less resembling taxa. Figs 137-138. SEM internal view: D. praetermissa, Brunnsee. 

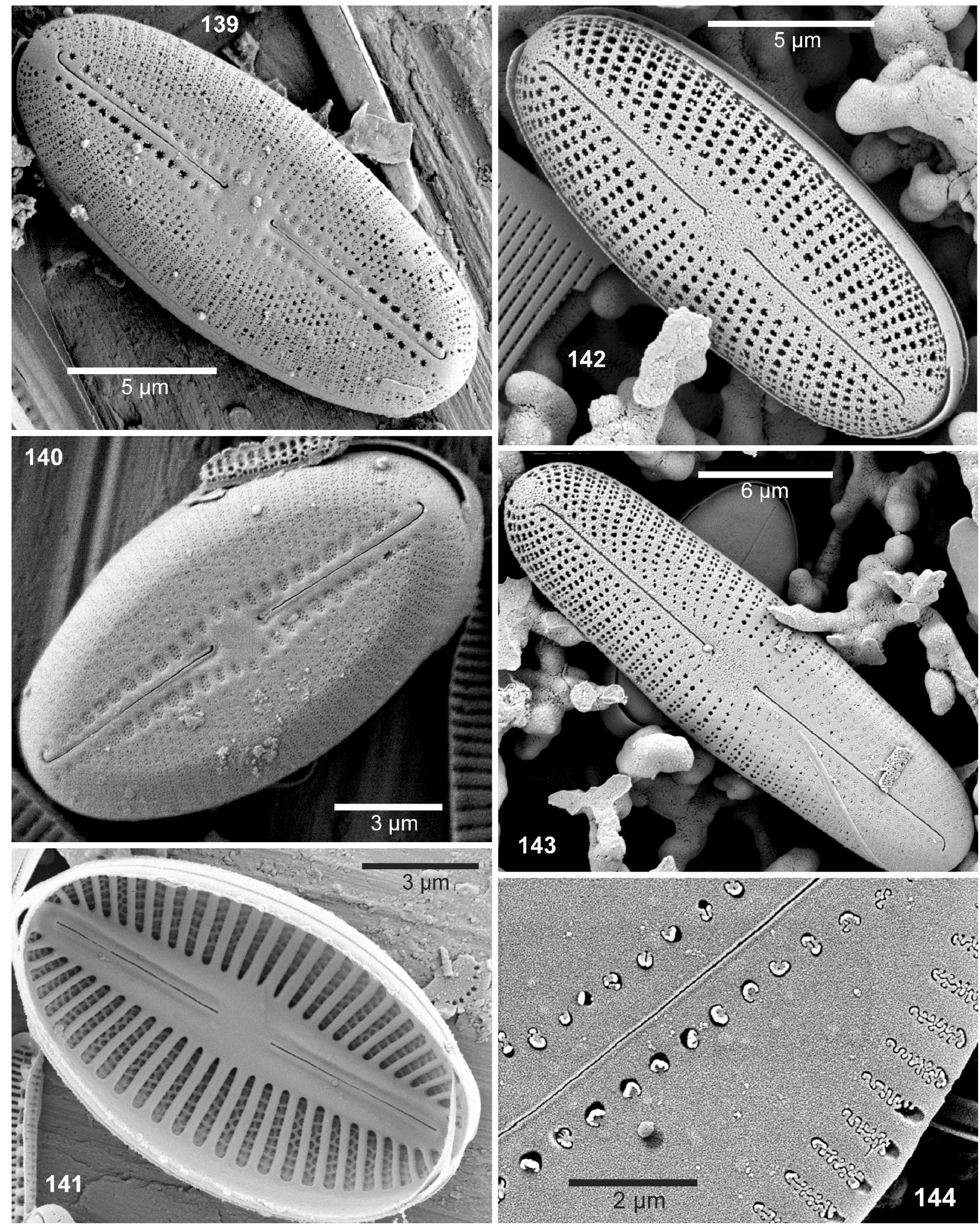

Figs 139-140. SEM external view: Diploneis tirolensis sp. nov., Weissensee. Note relief-like depressed large canal cribra comparable to D. praetermissa but shortly hooked raphe ends. Fig. 141. SEM internal view: D. tirolensis, Weissensee. Figs 142-143. SEM external view: Diploneis separanda Lange-Bertalot, Marbe. For comparison with resembling new taxa. Fig. 144. SEM external view: Diploneis spec. 1 cf. oculata, Lake Baikal. Sinuous foramina (volae), see also Fig. 145 internal view. These and the following Figs 146-150 (two taxa) represent morphologically different goups (sections) with other than cribrate areolae patterns in Diploneis. 

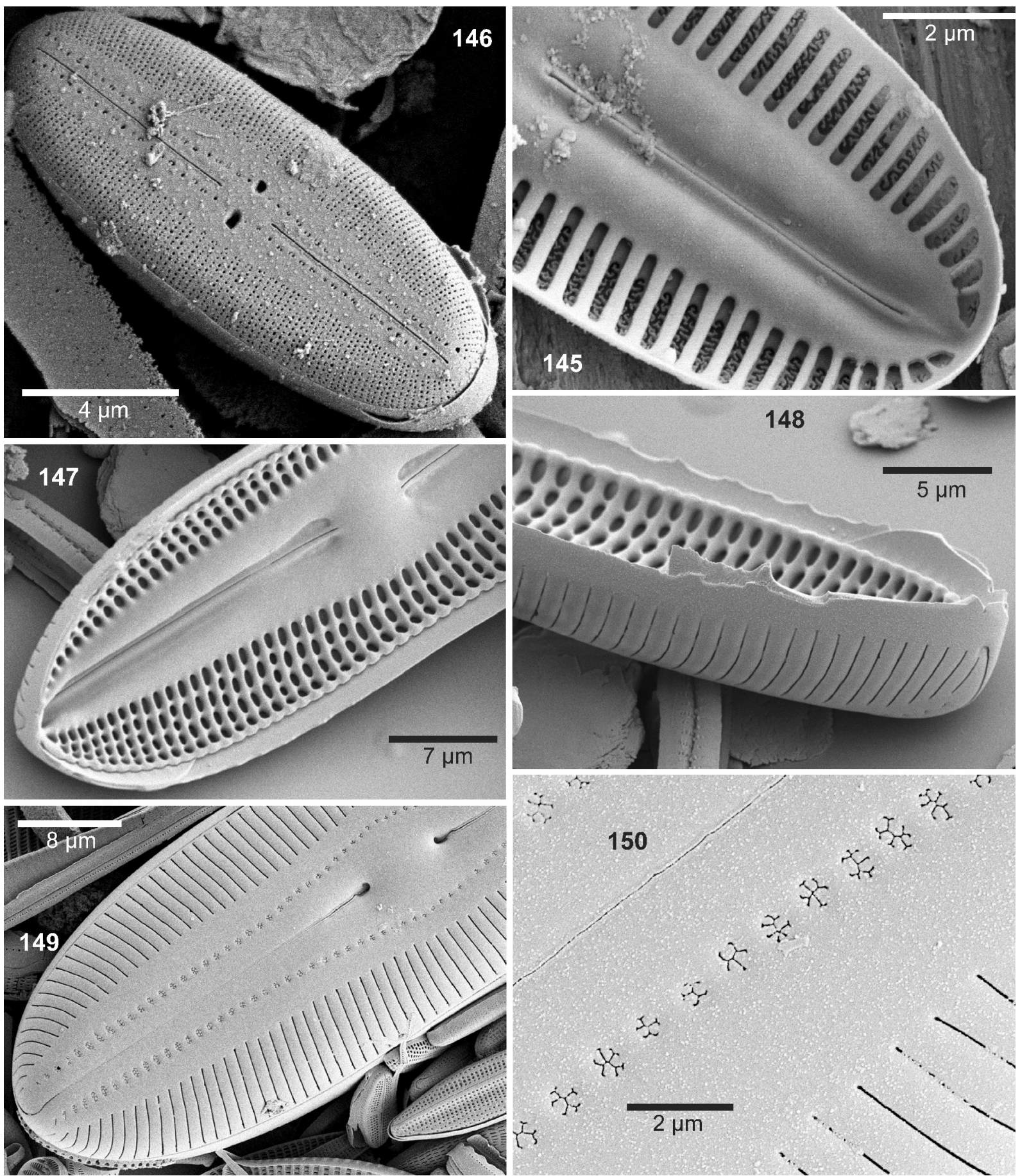

Fig. 145. SEM internal view: $D$. spec. 2 cf. oculata, Weissensee. Alveoli not subdivided by areolae, sinuous slits visible on the outside (volae). Fig. 146. SEM external view: Diploneis petersenii Hustedt, Weissensee. Biseriate small circular foramina instead of cribra. Figs 147-148. SEM internal (147), SEM external side view to valve face and mantle, (148) D. alpina Meister, Bohinj. Coarse areolae pattern only recognizable internally. Figs 149-150. SEM external view: D. alpina Meister, Bohinj. See explanation under Conclusion.

Zona canalium distincta signata linea apicali punctorum singularium arcuata circum nodulum centralem. Striae transapicales radiantes omnino fere constanter 20-22.5 in $10 \mu \mathrm{m}$. Areolae numquam discernendae microscopio photonico. Aspectus externus internusque microscopio electronico vide Figs 139-141. Extrema centralia raphis curte deflexa unilateraliter. Extrema apicalia distinctissime uncinata (ita differentia a specie
Diploneis praetermissa et alteris speciebus similibus.) Areolae stiarum biseriatae alternantes, $32-35$ in $10 \mu \mathrm{m}$ in linea unaquisque. Areolae omnes cribratae compositae paucis (3-4 raro 5) poris.

Holotype (designated here): Slide Eu-A 198 in Coll. Lange-Bertalot, Naturmuseum Senckenberg, Frankfurt (FR), represented by Fig. 78 . 
Type locality: Weissensee, an alpine lake, oligotrophic and rich in calciumcarbonate, $1050 \mathrm{~m}$ a.s.l., near Lermoos, Tyrol, Austria; leg. K. Külbs, Sept. 1982.

Etymology: The latinised adjective tirolensis refers to Tyrol, alpine region in Austria, where this species was first encountered.

\section{Description}

Valves elliptical, largest cell cycle stages linear-elliptical, ends broadly rounded. Length 9-21 $\mu \mathrm{m}$, breadth 6.4-7 $\mu \mathrm{m}$. Length-to-breadth ratio 1.6-3.0. Raphe filiform, straight, without recognizable peculiarities at central and distal ends. Axial area linear, very narrow or slightly expanded proximally. Central area distinctly separated, at least in larger stages, with the central nodule appearing approximately circular to apically elliptical, extended somewhat less than a quarter of the valve breadth. Internal axial canals distinct, marked by an apical line of single puncta on either side, expanded around the central nodule. Striae clearly radiate throughout from the centre up to the ends., consistently 20-22.5 in $10 \mu \mathrm{m}$. Areolae even with strongly oblique lighting not discernible. SEM external view see Figs 139-40. Raphe with shortly bent central ends; proximal part of the raphe slit, including the ends, lying in a delicate raphe rib. Distal ends curving into longer, weakly pronounced fish-hook shaped terminal fissures. Areolae strictly biseriate throughout, consisting of alternating stigmoid-poor small cribra, $32-35$ in 10 $\mu \mathrm{m}$. Internal view see Fig. 141. Remarkable is the difference between the breadth of the virgae and that of the striae (alveoli), the first measuring ca. 0.3-0.4 $\mu \mathrm{m}$, the latter being narrower at least in all proximal and subproximal parts of the valve.

Differential description vs. Diploneis praetermissa sp. nov. and some other small-celled taxa

D. praetermissa may be distinguished in LM view by its proximally less radiate and throughout less densely spaced striae (17-19 instead of 20-22.5 in $10 \mu \mathrm{m})$. Particularly conspicuous in SEM view is the different course of the raphe ends, its longer terminal fissures bending onto the mantle (not hooked). The central raphe ends describe clearly a more widely rounded hook. The canal cribra are constantly larger. Internally the striae (alveoli) are broader than the virgae. - Diploneis oblongellopsis has unseriate areolae, visible throughout even in LM. The raphe course differs in SEM. - Diploneis separanda (see Differential Description of $D$. praetermissa) has coarser striae, less than 20 in $10 \mu \mathrm{m}$. The fine structure pattern in SEM is different (cf. Figs. 139 and 142). - Diploneis nanofontanella sp. nov. has a higher ratio of length-to-breadth, 3.3-4.0 (not 1.6-3.0). The central area is larger, ca. half of the valve breadth. The breadth of the internal canal system is ca. half (not a quarter) of the valve breadth. Internal apical furrows flanking the raphe are not parallel near the central nodule. - Other more or less similar small- celled taxa with densely spaced striae can hardly be mistaken for $D$. tirolensis in view of the parallel striae system with a different areolae pattern as e.g. in $D$. oculata or D. petersenii.

\section{Distribution and ecology}

D. tirolensis is as yet known from three oligotrophic, calciumcarbonate-rich lakes in Austria and Bavaria. It was not observed in other comparable lakes. However, one should consider that such small-sized Diploneis taxa have not been critically investigated in the past but possibly misidentified in routine records under the catch-all name Diploneis oblongella. At the type location the taxon grows epiphytically together with $D$. praetermissa, two taxa which are difficult to distinguish at first glance in LM and even in SEM view. Only on closer examination can the two be distinguished, principally by their differing striae density, by the more or less radiate striae position in the valve centre, and by the terminal raphe fissures being much longer in $D$. praetermissa.

\section{Taxonomical comments}

Apart from D. praetermissa, D. tirolensis may also easily be confused with $D$. oblongellopsis or $D$. separanda. If all four taxa were to occur in a single sample, their separation may be an intricate task in LM view. In SEM view, however, the respective characteristics of the raphe hold a key towards precisely distinguishing between otherwise similar taxa, as in various other genera.

Diploneis tundra Lange-Bertalot et A. Fuhrmann sp. nov. (Figs 93-97 LM)

Syonyms: D. parma Cleve sensu Lange-Bertalot \& Genkal 1999 , fig. 43: 4; "Diploneis sp. 1" sensu Antoniades et al. 2008, pp. 95-96, figs 36: 2-3, 12-13, 102: 6-7; D. parma Cleve sensu Metzeltin et al. 2009; figs 109: 1-2, 4-9.

Diagnosis differens versus Diploneis hinziae sp. nov. (vide supra)

Valvae stricte ellipticae apicibus late rotundis, 28-32 $\mu \mathrm{m}$ longae, 15-17 $\mu \mathrm{m}$ latae. Raphe et area axialis cum alteris structuris typicis non differunt. Area centralis anguste rectangulata (non transapicaliter dilatata elliptica). Striae transapicales $11-12$ in $10 \mu \mathrm{m}$ cum areolis numquam duplicatis, 10-12 (non 14-18) in $10 \mu \mathrm{m}$.

Holotype (designated here): Slide RUS-38 in Coll. Lange-Bertalot, Naturmuseum Senckenberg, Frankfurt (FR), from sample B-4 in Coll. S. Genkal, Borok, Russia, represented by Fig. 93.

Type locality: Mestnyi Island, Yugorski-Shar Strait, Arctic Ocean, near Yugorski Peninsula; on bryophytes of a freshwater river, leg. N.V. Vekhov, Sept. 1995.

Etymology: The epithet refers to the tundra plant association of the Arctic Circle. 


\section{Differential description versus Diploneis hinziae sp.} nov. (see above)

Valves broadly elliptical with broadly rounded ends; valve face flat, gently arcuate only in marginal parts, gradually passing over to the valve mantle. Length 28-35 $\mu \mathrm{m}$, breadth 15-17 $\mu \mathrm{m}$. Raphe filiform, straight, delicate, flanked on both sides by a narrow internal depression. Central and distal ends of the raphe inconspicuous, the former not expanded. Axial area narrow and rather straight, congruent with raphe sternum and flanking depressions. Central area narrow, rectangular, sometimes very slightly constricted in the middle (not moderately expanded elliptically). Axial internal canals narrow, marked externally by short striae composed of two areolae on either side. The entire axial area including the canals is shaped extremely narrowlanceolate. The adjacent regular transapical striae are slightly radiate, becoming more radiate only near the poles, $11-12$ in $10 \mu \mathrm{m}$. Areolae appearing uniseriate throughout, including the junction between valve face and mantle, 10-12 (not 14-15) in $10 \mu \mathrm{m}$. The interstriae (virgae) are very narrow in comparison with the areolated striae.

SEM external and internal view see ANTONIADES et al. 2008, figs 102: 6-7. Both confirm the observations with LM techniques without giving more detailed information for identification among comparable taxa. However, in the marginal part of the mantle few areolae become biseriate in external view (not mentioned by Antoniades et al. 2008).

\section{Distribution and ecology}

As yet critically observed only at type locality in pristine oligotrophic water associated with several Eunotia and Pinnularia taxa. Another doubtless conspecific population was described and depicted in LM and SEM photographs from the Canadian Arctic Archipelago by ANTONIADES et al. 2008 (see above under Synonyms).

\section{Comments}

Other taxa similar with respect to valve outlines and size dimensions differ by more expanded central areae, internal canals more distinctly arched around the central nodule, and/or different numbers of striae and areolae in $10 \mu \mathrm{m}$.

\section{Conclusions}

In the present paper we have continued some previous contributions to the group of freshwater Diploneis species that are morphologically characterised and distinguished by cribrate areolae. In the case of three already established infraspecific taxa we have argued that they merit the rank of independent species. We have described and proposed as new to science twelve further species previously overlooked, neglected or misidentified. In general the known freshwater Diploneis taxa may be divided into four groups according to four distinctive clusters of valve structure patterns. These patterns can be reliably identified only with the help of transmission (TEM) or scanning (SEM) electron microscopy. As far as we know, the second and third group (see below) subsume exclusively small-celled taxa like $D$. minuta Petersen or $D$. petersenii Hustedt. The groups (sections) are as follows:

Cribrate areolae of various size yet no other types of areolae present. Striae uniseriate or biseriate. Sometimes striae arrangements switch over from uniseriate close to the canals to bi- or pluriseriate towards the margins of the mantle. By far most of the freshwater taxa in Europe and elsewhere exhibit this combination of characteristics. This is the group under study in the present paper.

Areolae never cribrate and in strictly biseriate arrangement, except possibly for those penetrating the canals. External foramina (poroids) very small and approximately circular. Examples are D. petersenii (see Fig. 146) and D. marginestriata HustedT (see IDEI \& KoBAYASI 1988).

Areolae pattern coarse, recognizable only internally. Externally without cribra, biseriate circular fine poroids or sinuous openings (volae). Instead we find uniseriate continuous narrow and occluded slits covering all marginal and submarginal parts of the valve face and mantle. In the canals some shorter slits arranged in the distal parts may occur, turning into more or less isodiametrical poroids in the proximal parts; alternatively all foramina of such areolae are occluded by several volae leaving a dendritic slit for communication between the outside and the canal inside like in many spp. of Didymosphenia (e.g. Metzeltin \& Lange-Bertalot 2014). See Figs 149-150 representing D. alpina MeISTER syn. D. subconstricta syn. D. domblittensis var. subconstricta. D. subconstricta (GrunOw) Cleve may be seen as exhibiting a modification of this structure pattern (see SnOeIJs \& PotAPova 1995, fig. 231).

Not areolated or otherwise subdivided alveoli in uniseriate arrangement, opening externally through a sinuous slit with partial branching. See Figs 144 and 145, and IDEI \& KoBAYAsi (1986) for D. oculata and D. minuta.

D. parma sensu Hustedt from the Swiss Alps proves to be a species different from $D$. parma P.T. Cleve from Finland and Sweden, including the type. We have therefore redescribed the first as a new species under the name $D$. hinziae. A broadly similar population from subtropical Florida, U.S.A., is described as a third independent species, D. parahinziae, belonging to the same group as detailed above.

$D$. lusatica and D. abscondita are described from a freshwater reservoir and a pond respectively, both in Germany and with moderately high conductivity resulting mainly from calcium sulphate.

D. tundra and D. nanofontanella have been observed in freshwater rivers of the Russian Arctic, 
geographically in the outmost northeastern region of Europe. The former occurs rarely but widespread in the Arctic zone of the American and Eurasian continents. The latter is as yet only known from the type locality; it is closely related but easily distinguished from $D$. fontanella which has been observed and in each case associated with acidophilous diatoms in Germany and the Holarctic regions.

D. calcilacustris, D. praetermissa, D. tirolensis, and D. oblongellopsis are frequent and locally abundant in carbonate-rich lakes. Most of them have been recorded and depicted in the literature by various authors under the names D. oblongella or D. ovalis var. oblongella; see the detailed discussion under D. oblongellopsis. D. calcilacustris and as yet undescribed aff. calcilacustris have also been mistaken for small-celled stages of $D$. parma sensu METZELTIN \& LANGE-BERTALоT (1996, figs 85: 5-7).

D. puellafallax could only recently be observed in subfossil sediments of Lake Laach, Eifel Mountains, Germany, a crater lake originating from volcanic activity, ca. 11.000 years BP. It does not conform to $D$. puella sensu Mölder \& TYNni 1973, sensu EhrLich (1995), or sensu Krammer \& LANGE-Bertalot (1986). It is associated with $D$. praetermissa, D. oblongellopsis, D. separanda, D. krammeri, D. calcilacustris, and D. elliptica.

D. modicahassiaca was found with an individual-poor population in a large artificial pond together with $D$. calcilacustris, $D$. oculata, and $D$. petersenii. Occasional occurrences elsewhere in Germany have very likely been overlooked.

In addition to the taxa presented in this paper, several cribrate Diploneis populations await SEM studies and will be published in the near future as new species, e.g. "Diploneis sp. 1" and "D. ovalis" sensu Germain 1981 as documented by Bey \& Ector (2013, pp. 417f.). Still required are SEM structure observations of $D$. ladogensis and $D$. dilatata. In the case of $D$. finnica (EhrENBERG) P.T. Cleve 1891 it will be necessary to designate an epitype, preferably from fossil type material found in Kymmene Gard, Finland. The epitype should be based on the lectotypified original line drawing of the basionym Cocconeis finnica EHRENBERG 1838 (first description without illustration) as published in EhrenBerg (1854, pl. 17, fig. II: 49). Ehrenberg's drawing hardly conforms to our actual concept of $D$. finnica. The latter is characterised by distinctly radiate striae, becoming very strongly radiate at the ends, whereas the drawing exhibits subparallel striae throughout. This invites the question as to whether the "icon" really does refer to what we now subsume under $D$. finnica. And further, are the commonly accepted later synonyms $D$. clevei FonTELl 1917 and $D$. $d u$ plopunctata FonTell 1917 correct names for what we identify as $D$. finnica rather than for Cocconeis finni$c a$ ? Unfortunately, apart from an original unpublished hand-drawing no specimen of Ehrenberg's taxon could be found in his collection (personal communication by R. Jahn, Botanical Museum in Berlin).

\section{ACKNOWLedgements}

We wish to thank Nicola Angeli, Malgorzata Bak, Friedel Hinz, Gabriele Hofmann, Klaus Külbs, Federica Nones, Michael Nörpel, Sarah Olischäger, Eveline Pinseel, Marina Potapova, Manfred Ruppel, Marcus Werum, and Andrzej Witkowski.

\section{REFERENCES}

Antoniades, D.; Hamilton, P.; Douglas, M.S.V. \& Smol, J.P. (2008): Freshwater diatoms of the Canadian High Arctic Islands: Ellef Ringnes, northern Ellesmere and Prince Patrick islands. - Iconographia Diatomologica 17: 1-649.

Bey, M.-Y. \& Ector, L. (2013): Atlas des diatomées des cours d'eau de la région Rhône-Alpes. - $1182+$ 27 pp., Direction régionale de l'Environnement, de l'Aménagement et du Logement Rhône-Alpes, Lyon.

Blanco, S.; Cejudo-Figueiras, C.; Álvarez-Blanco, I.; Bécares, E.; Hoffmann, L. \& Ector, L. (2010): Atlas de las Diatomeas de la Cuenca del Duero / Diatom Atlas of the Duero Basin. - 383 pp., Área de Publicaciones, Universidad de León, Léon.

Cleve, P.T. (1891): The diatoms of Finland. - Acta Soc. Fauna et Flora Fennica 8: 1-68, 3 pls.

Cleve, P.T. (1894): Synopsis of the Naviculoid Diatoms, Part I. - Kongliga Svenska-Vetenskaps Akademiens Handligar 26: 1-194, 5 pls.

Cleve-Euler, A. (with A.L. Beckmann) (1922): Die fossile Diatomaceenflora in Österbotten. - Acta Forestalia Fennica 22: 1-73, 37 fig., 18 tables.

Cleve-Euler, A. (1953): Die Diatomeen von Schweden und Finnland. Part III. Monoraphideae, Biraphideae 1. Kongliga Svenska Vetenskaps-Akademiens Handligar, ser. 4, vol. 4: 1-255, figs 484-970.

Ehrlich, A. (1995): Atlas of the Inland-water diatom flora of Israel. - In: Por, F.D. (ed.): Flora Palaestina. - 166 pp., Geological Survey of Israel, Israel Academy of Science and Humanities, Jerusalem.

Foged, N. (1976): Diatoms from the Alhambra, Granada, Spain. - Nova Hedwigia 27: 881-901.

Foged, N. (1977): Freshwater diatoms in Ireland. - Bibliotheca Diatomologica 34: 1-222.

Foged, N. (1981): Diatoms in Alaska. - Bibliotheca Phycologica 53: 1-317.

Germain, H. (1981): Flore des diatomées - Diatomophycées - eaux douces et saumâtres du Massif Armoricain et des contrées voisines d'Europe occidentale. - 444 pp., Collection "Faunes et Flores Actuelles", Société Nouvelle des Editions Boubée, Paris.

Hofmann, G.; Werum M. \& Lange-Bertalot, H. (2013): Diatomeen im Süßwasser-Benthos von Mitteleuropa, 2nd ed. - 908 pp., Koeltz Scientific Books, Königstein.

Hustedt, F. (1930): Bacillariophyta (Diatomeae). - In: A. Pascher (ed.): Die Süsswasser-Flora Mitteleuropas, Heft 10, 2. Aufl. -466 pp, 875 figs, G. Fischer, Jena.

Hustedt, F. (1937): Die Kieselalgen Deutschlands, Öster- 
reichs und der Schweiz unter Berücksichtigung der übrigen Länder Europas sowie der angrenzenden Meeresgebiete. - In: L. RabENHORST (ed.): Kryptogamen Flora von Deutschland, Österreich und der Schweiz, Vol: 7, Issue: Teil 2, Lief. 5. - pp. 577-736, Akademische Verlagsgesellschaft, Leipzig.

Hustedt, F. (1943): Die Diatomeenflora einiger Hochgebirgsseen der Landschaft Davos in den Schweizer Alpen. - Internationale Revue der gesamten Hydrobiologie und Hydrographie 43: 124-197, 225-280.

Hustedt, F. (1945): Diatomeen aus Seen und Quellgebieten der Balkan-Halbinsel. - Archiv für Hydrobiologie 40: 867-973.

Idei, M. \& Kobayasi, H. (1988a): Examination of the type specimens of Diploneis parma Cl. - In: F.E. Round (ed.): Proc. 9th Intern. Diatom Symp. - pp. 397-403, Biopress, Bristol.

IdeI, M. \& Kobayasi, H. (1988b): A light electron microscope study of the benthic diatom Diploneis marginestriata Hust. (Bacillariophyceae). - Japanese Journal of Phycology 36: 277-284.

Jovanovska, E.; NAKov, T. \& Levkov, Z. (2013): Observations of the genus Diploneis from Lake Ohrid, Macedonia. - Diatom Research 28: 237-262.

Jovanovska, E.; Levkov, Z. \& EdLund, M. (2015): The genus Diploneis Ehrenberg ex Cleve (Bacillariophyta) from Lake Hövsgöl, Mongolia. - Forthcoming.

Krammer, K. \& Lange-Bertalot, H. (1986): Bacillariophyceae 1. Teil. Naviculaceae. - In: ETTL, H.; GÄrTNER, G. \& Mollenhauer, D. (eds): Süsswasserflora von Mitteleuropa. - 876 pp., Gustav Fisher Verlag, Stuttgart, New York.

LANGe-Bertalot, H. (1996): Rote Liste der limnischen Kieselalgen Deutschlands. - Schriftenreihe für Vegetationskunde 28: 633-677.

LANGE-Bertalot, H. (2001): Navicula sensu stricto. 10 Genera separated from Navicula sensu lato. Frustulia. Diatoms of Europe 2: 1-526.

Lange-Bertalot, H. \& Metzeltin, D. (1996): Indicators of Oligotrophy. 800 Taxa representative of three ecologically distinct lake types. - Iconographia Diatomologica 2: 1-390.

Lange-Bertalot, H. \& Genkal, S.I. (1999): Diatomeen aus Siberien, I. Insel im Arktischen Ozean (YugorskyShar Strait). - Iconographia Diatomologica 6: 1-303.

Lange-Bertalot, H. \& ReichHardt, E. (2000): Diploneis ovalis sensu stricto und Diploneis krammeri nov. spec. Revision des aktuellen Konzepts von Diploneis ovalis (Hilse) Cleve. - Iconographia Diatomologica 9: 650-669.

Levkov, Z.; Krstic, S.; Metzeltin, D. \& Nakov, T. (2007): Diatoms of Lakes Prespa and Ohrid. - Iconographia Diatomologica 16: 1-613.

Metzeltin, D. \& Witkowski, A. (1996): Diatomeen der Bären-Insel. Süsswasser- und marine Arten. Iconographia Diatomologica 4: 3-217.

Metzeltin, D.; Lange-Bertalot, H. \& Nergui, S. (2009): Diatoms in Mongolia. - Iconographia Diatomologica 20: 3-686.

Metzeltin, D. \& Lange-Bertalot, H. (2014): The genus Didymosphenia M. Schmidt. A critical evaluation of established and description of 11 new taxa. - Iconographia Diatomologica 25: 1-293.

MöLDER, K. \& TynnI, R. (1973): Über Finnlands rezente und subfossile Diatomeen VII. - Bull. Geol. Soc. Finland 45: 159-179.

Patrick, R.M. \& Reimer, C.W. (1966): The Diatoms of the United States exclusive of Alaska and Hawaii, vol. 1: Fragilariaceae, Eunotiaceae, Achnanthaceae, Naviculaceae. -688 pp., Academy of Natural Sciences of Philadelphia, Philadelphia.

Reichhardt, E. \& Lange-Bertalot, H. (2014): Eine Diatomeenassoziation in einem Quellhabitat im Grazer Bergland, Österreich: Ein Beitrag zur Kenntnis seltener und wenig bekannter Diatomeen. - Iconographia Diatomologica 13: 419-479.

Schumann, J. (1867): Preussische Diatomeen, Zweiter Nachtrag. - Schriften der königlichen physikalischökonomischen Gesellschaft zu Königsberg 8: 37-68, 3 pls.

Snoeis, P. \& Potapova, M. (1995): Intercalibration and distribution of diatom species in the Baltic Sea, vol. 3. - 126 pp., Opulus Press, Uppsala.

Werum, M. \& Lange-Bertalot, H. (2004): Diatoms in springs from Central Europe and elsewhere under the influence of hydrogeology and anthropogenic impacts. - Iconographia Diatomologica 13: 3-417.

Witkowski, A., Lange-Bertalot, H. \& Metzeltin, D. (2000): Diatom flora of marine coasts I. - Iconographia Diatomologica 7: 1-925.

ZelazNA-WieCZOREK, J. (2011): Diatom flora in springs of Lodz Hills (Central Poland). Biodiversity, taxonomy, and temporal changes of diatom assemblages in springs affected by human impact. - Diatom Monographs 13: 1-419

(C) Czech Phycological Society (2016)

Received August 17, 2015

Accepted October 11, 2015 